\title{
The Lipolysome-A Highly Complex and Dynamic Protein Network Orchestrating Cytoplasmic Triacylglycerol Degradation
}

\author{
Peter Hofer ${ }^{1}$, Ulrike Taschler ${ }^{1}{ }^{\circledR}$, Renate Schreiber ${ }^{1}$, Petra Kotzbeck ${ }^{2}$ and \\ Gabriele Schoiswohl 1,*(D) \\ 1 Institute of Molecular Biosciences, University of Graz, 8010 Graz, Austria; peter.hofer@uni-graz.at (P.H.); \\ ulrike.taschler@uni-graz.at (U.T.); renate.schreiber@uni-graz.at (R.S.) \\ 2 Division of Endocrinology and Diabetology, Department of Internal Medicine, Medical University of Graz, \\ 8036 Graz, Austria; petra.kotzbeck@medunigraz.at \\ * Correspondence: gabriele.schoiswohl@uni-graz.at
}

Received: 13 March 2020; Accepted: 8 April 2020; Published: 10 April 2020

\begin{abstract}
The catabolism of intracellular triacylglycerols (TAGs) involves the activity of cytoplasmic and lysosomal enzymes. Cytoplasmic TAG hydrolysis, commonly termed lipolysis, is catalyzed by the sequential action of three major hydrolases, namely adipose triglyceride lipase, hormone-sensitive lipase, and monoacylglycerol lipase. All three enzymes interact with numerous protein binding partners that modulate their activity, cellular localization, or stability. Deficiencies of these auxiliary proteins can lead to derangements in neutral lipid metabolism and energy homeostasis. In this review, we summarize the composition and the dynamics of the complex lipolytic machinery we like to call "lipolysome".
\end{abstract}

Keywords: lipolysis; adipose tissue; triacylglycerol; lipase; fatty acid; lipid biochemistry; lipid droplets

\section{Introduction}

The stepwise enzymatic hydrolysis of intracellular triacylglycerols (TAGs) is a central biochemical process occurring in virtually every cell or tissue type. Depending on the origin of TAGs, two distinct pathways mediate their degradation [1]. Lipoprotein-derived TAGs are mostly delivered to lysosomes and hydrolyzed by lysosomal acid lipase at acidic $\mathrm{pH}$, while TAGs that are stored in cytoplasmic lipid droplets (LDs) are predominantly hydrolyzed by cytosolic enzymes at neutral $\mathrm{pH}$. Depending on the cell type, autophagy and lysosomal hydrolysis can also contribute to the degradation of LD-associated TAGs [2]. Lipolytic products, including diacylglycerols (DAGs), monoacylglycerols (MAGs), fatty acids (FAs), and glycerol, serve as energy resources, building blocks for lipid remodeling, or membrane biosynthesis, and signaling molecules influencing gene transcription or enzyme activity (Figure 1) [3,4]. Considering these pleotropic functions, it is obvious that lipolysis needs to be tightly controlled to ensure metabolic homeostasis. As a consequence, dysregulated or dysfunctional lipolysis is associated with severe pathological conditions, including obesity, lipodystrophy, cardiovascular disease, insulin resistance, fatty liver disease, cancer, or cancer-associated cachexia [5]. 


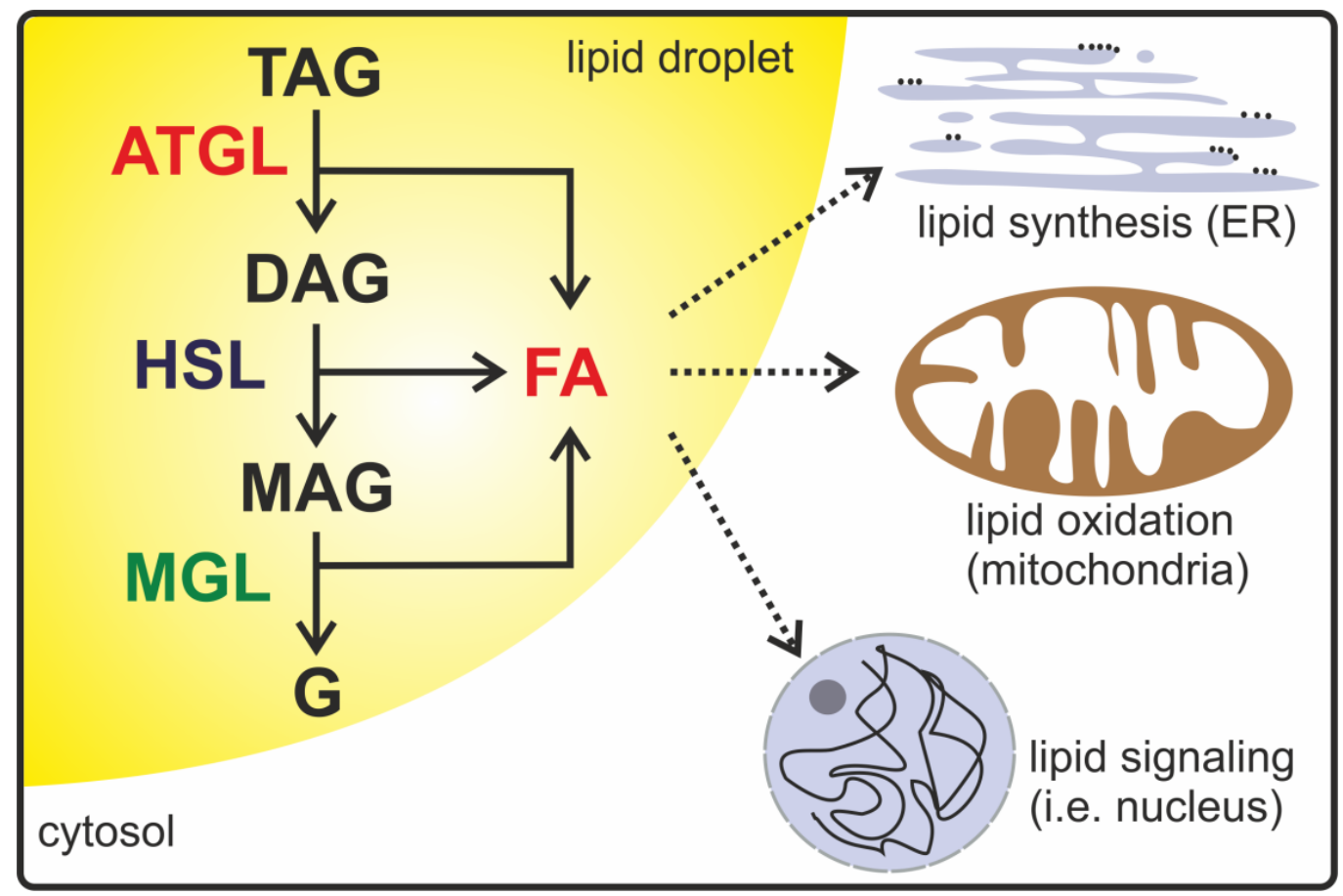

Figure 1. A schematic description of intracellular lipolysis. In the lipolytic active state, adipose triglyceride lipase (ATGL), hormone-sensitive lipase (HSL), and monoacylglycerol (MAG) lipase (MGL) are localized on the surface of lipid droplets in the cytoplasm. ATGL catalyzes the initial step in triacylglycerol (TAG) hydrolysis, generating diacylglycerol (DAG) and fatty acids (FAs). HSL preferentially degrades DAG into MAG and FAs. In the last step, MGL releases FAs and glycerol (G). Lipolytic products such as DAG, MAG, FAs, and glycerol are used as energy resources, signaling lipids, or precursors for lipid synthesis and membrane biosynthesis.

The three major enzymes facilitating cytoplasmic lipolysis are adipose triglyceride lipase (ATGL), hormone-sensitive lipase (HSL), and MAG lipase (MGL). Studies on the spatial and temporal regulation of these enzymes revealed unexpected complexity by uncovering ATGL, HSL, and MGL protein interaction partners modulating enzyme activity, localization, stability, or affinity to other proteins. Deficiency of many of these auxiliary proteins leads to pronounced alterations in neutral lipid metabolism and associated processes [6-10]. Thus, intracellular lipolysis, equivalently to gastrointestinal lipolysis [11] or lipogenesis [12], depends on the interactions of its enzymes with a broad set of regulatory proteins. The term "lipolysome" —initially introduced by Rudolf Zechner-describes the complexity of the lipolytic machinery. Here, we concisely summarize the current knowledge about the molecular composition and functionality of the lipolysome (Figure 2). 


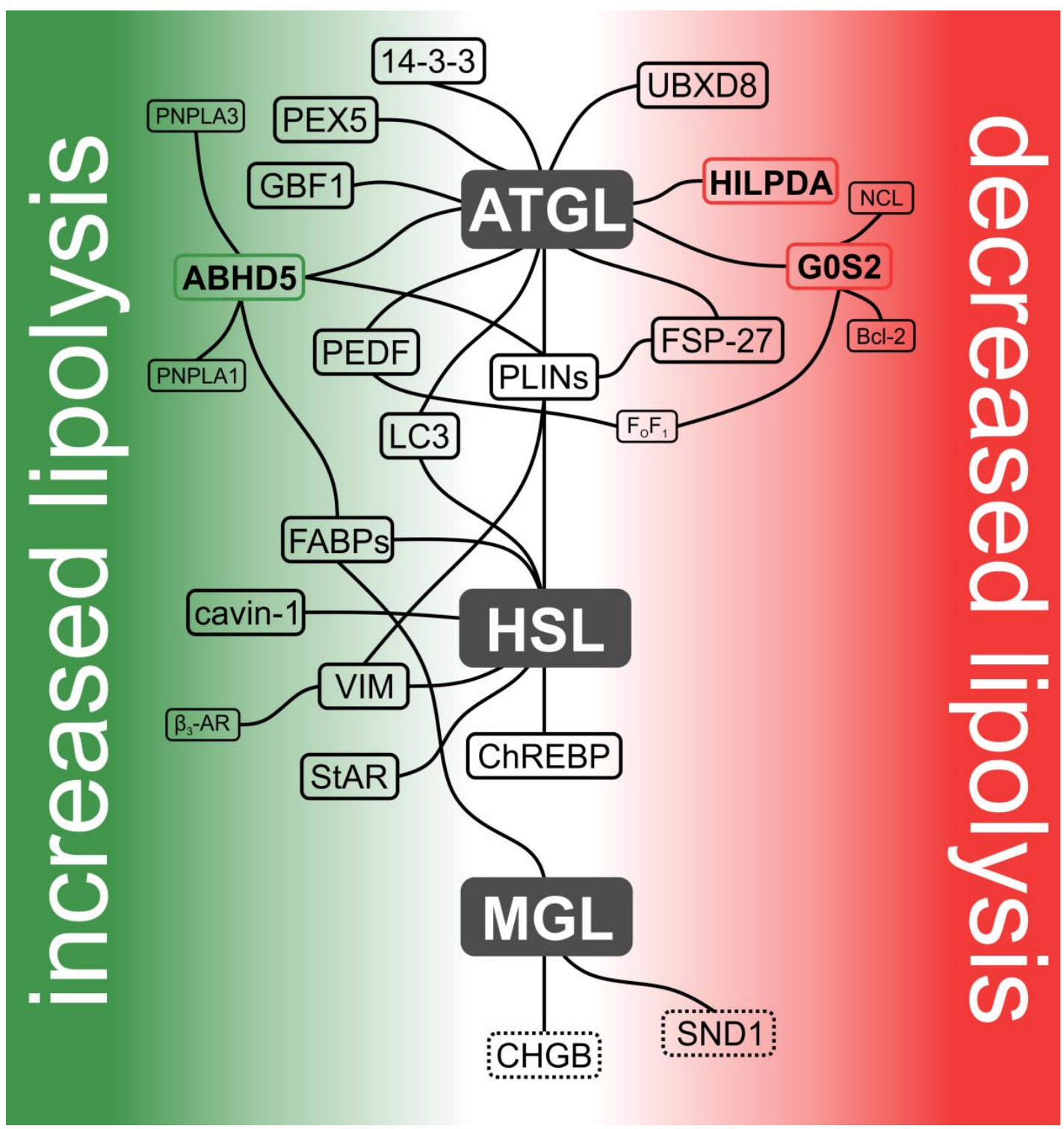

Figure 2. Current model of the lipolysome. Hydrolysis of intracellular TAGs is catalyzed by the sequential action of ATGL, HSL, and MGL. Together with their protein interaction partners, these lipases form a dynamic protein assembly designated as the lipolysome. Interaction partners that activate enzyme activities are depicted in the green area, while those that inhibit enzyme activities are shown in the red area. Proteins directly affecting enzyme activity are highlighted in bold and in colored boxes accordingly (in green: activating and in red: inhibiting). Proteins indirectly affecting lipase activities are shown in black boxes. Putative binding partners are shown in dashed boxes. Lipase-independent interaction partners are shown in smaller font. Interaction partners not affecting lipase activity per se (CHGB (chromogranin B) and carbohydrate response element binding protein (ChREBP)) or having divergent effects on ATGL and HSL (perilipins (PLINs)) are located in the center.

\section{ATGL and Its Interaction Partners}

In 2004, ATGL (officially annotated as patatin-like phospholipase domain containing 2, PNPLA2; also known as desnutrin and iPLA2-zeta) was identified as a robust TAG hydrolase, leading to a paradigm shift in the understanding of intracellular TAG breakdown [13-15]. ATGL is expressed in most tissues with highest levels detected in white and brown adipose tissue (AT). ATGL is a potent TAG hydrolase, preferentially cleaving long-chain FAs at the sn-2 position of the glycerol backbone [16]. Additionally, it exhibits minor phospholipase [17], DAG transacylase [15], and 
retinyl ester hydrolase activities [18]. Although the three-dimensional structure of ATGL remains to be determined, sequence-based structure predictions shed some light on the enzyme's domain organization (Figure 3). ATGL belongs to the PNPLA family, with an alpha/beta/alpha sandwich architecture and a patatin domain in the $\mathrm{N}$-terminal half of the protein. This domain contains the catalytic dyad composed of Ser47 located within a GXSXG motif and Asp166 [19]. A hydrophobic amino acid region stretches from Val315 to Ile364 that is essential for the LD localization of the enzyme. The C-terminal region of ATGL also possesses a negative auto-regulatory function [20]. Phosphoproteomic studies revealed that murine ATGL has at least eight phosphorylation sites [21]. The functional relevance of two of these phosphorylation sites has been investigated in more detail. Phosphorylation at Ser406 increases the TAG hydrolase activity of ATGL [22], whereas phosphorylation at Thr372 abrogates its LD localization [21]. The respective kinases are still a matter of controversy.

Consistent with its crucial role in lipolysis and energy homeostasis, the loss of ATGL activity provokes severe metabolic perturbations in many species. ATGL-knockout $(\mathrm{KO})$ mice accumulate TAGs in most tissues and die prematurely from cardiomyopathy [23]. The cardiac dysfunction also leads to a severe defect in thermogenesis in ATGL-KO mice [24]. Defective TAG utilization in ATGL-KO mice causes a shift from FA to glucose oxidation, which is associated with increased insulin sensitivity and glucose tolerance $[23,25]$. Resistance to high-fat diet-induced obesity in ATGL-KO mice indicates that ATGL is linked to lipid synthesis and AT growth [25]. In humans, loss of function mutations in the ATGL gene cause a rare, autosomal recessive condition called neutral lipid storage disease with myopathy (NLSD-M) [26]. The clinical manifestations of NLSD-M patients resemble the phenotype of ATGL-KO mice with respect to TAG accumulation in ectopic tissues, including peripheral leukocytes, and progressive (cardio)myopathy [5].

Over time, it became clear that ATGL and the other lipolytic enzymes do not act in solitude but instead interact with numerous protein partners within the lipolysome. Currently, more than a dozen proteins are known to bind to ATGL and affect its enzymatic properties. ATGL's interaction partners and site of interaction are highlighted in Figures 2 and 3. 


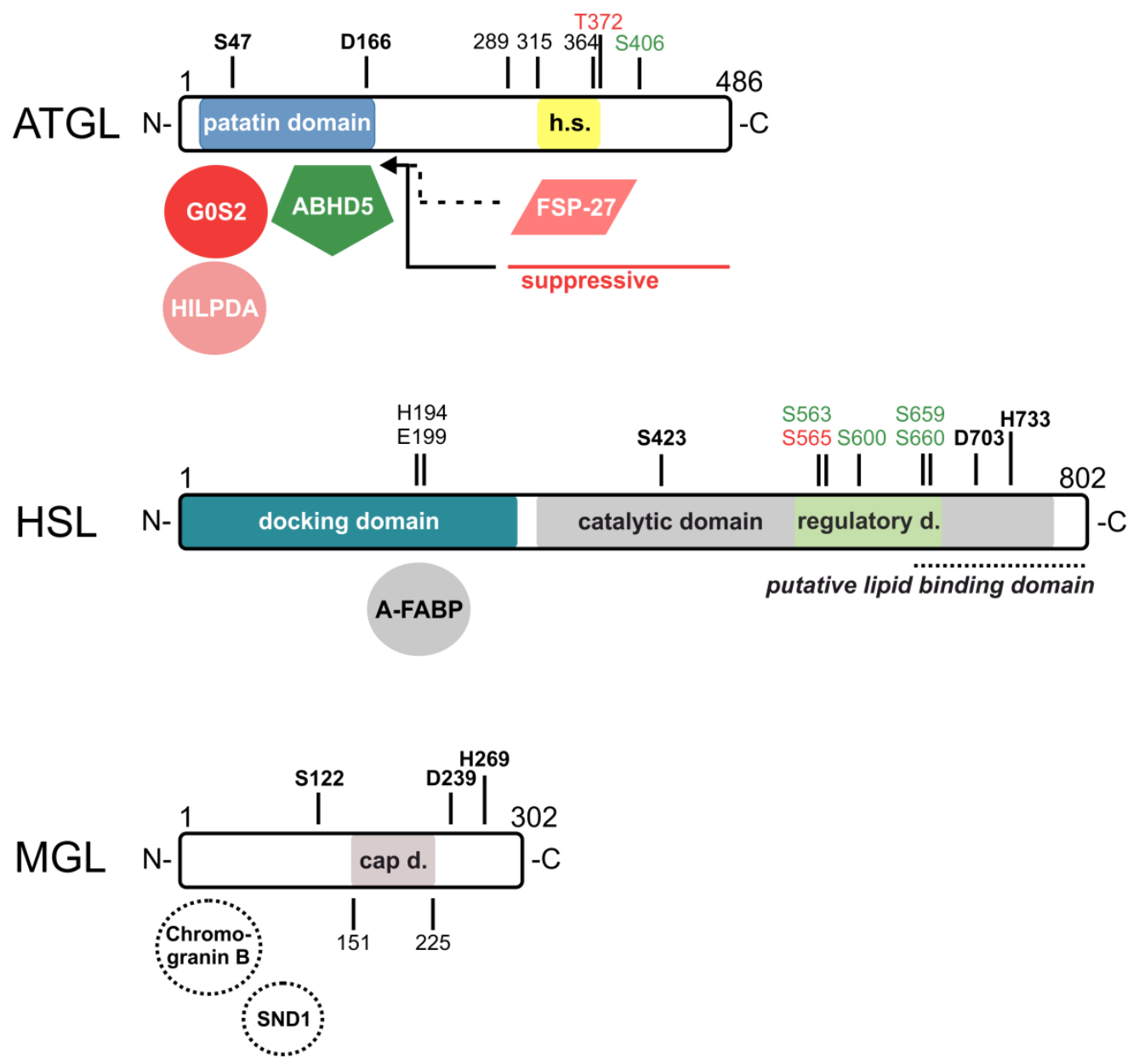

Figure 3. Domain structures and identified sites of (putative) interaction partners of ATGL, HSL, and MGL. For murine ATGL, the catalytic dyad consists of S47 and D166 within the patatin domain at the $\mathrm{N}$-terminus. This domain serves as a docking domain for the co-activator alpha/beta-hydrolase domain containing protein 5 (ABHD5) and the inhibitors G0/G1 switch gene 2 (G0S2) and hypoxia-inducible LD-associated protein (HILPDA) of ATGL. At the C-terminus, ATGL contains a hydrophobic stretch (h.s.) from amino acids 315-364 that is essential for lipid droplet (LD) localization. The phosphorylation of T372 abrogates LD localization and that of S406 increases the enzymatic activity of ATGL. The C-terminus from amino acids 289-486 suppresses enzymatic activity and might interfere with ABHD5 interactions. Fat-specific protein-27 (FSP27) possibly interferes with LD localization or with ABHD5 interaction (dashed lines). For murine HSL, the N-terminus serves as a docking domain for interaction partners. Adipocyte-type fatty acid-binding protein (A-FABP) binds to amino acids 192-200, with H194 and E199 being critical for interaction. The C-terminal domain contains the catalytic domain (grey) consisting of S423, D703, and H733, and within that, a regulatory domain (light green) with five phosphorylation sites that regulate HSL localization and activity, and a putative lipid binding domain (italics, dashed line). For human MGL, the active site consists of S122, D239, and H269, and the cap domain (grey) covering the active site that stretches from amino acids 151 to 225. Putative binding partners that may regulate activity or protein expression are indicated by dashed circles (SND1, Staphylococcal nuclease and tudor domain containing 1). Amino acids of the catalytic sites are highlighted in bold. Co-regulators/amino acids that activate enzyme activity are highlighted in green; those who inhibit enzyme activity are highlighted in red color tones. 


\subsection{Alpha/Beta-Hydrolase Domain Containing Protein 5 (ABHD5)}

Two years after the identification of ATGL, a potent activator of its activity was discovered. ABHD5 (also annotated as comparative gene identification-58, CGI-58) binds to ATGL and stimulates its TAG and retinyl ester hydrolase activities [18,27]. ABHD5 exhibits a broad tissue expression pattern with highest abundance in white and brown AT [28]. The exact molecular mechanism by which ABHD5 activates ATGL remains elusive. However, several structural domains in both ATGL and ABHD5 have been identified to be crucial for activation. ABHD5 interacts with the patatin domain of ATGL, but the exact amino acid residues involved in the interaction are not known $[19,20]$. Interestingly, a truncated ATGL variant lacking 220 C-terminal amino acids (where amino acids 1 to 289 are still present) shows an increased binding affinity to ABHD5 and a higher TAG hydrolase activity, indicating that the C-terminus of ATGL interferes with its interaction with ABHD5 [20]. Within ABHD5, the 30 N-terminal residues harbor a lipophilic tryptophan-rich stretch, which is crucial for both LD localization and ATGL activation [29]. Recent data indicate that Arg299 and Gly328 located near the C-terminus of ABHD5 are also important for activating ATGL-dependent lipolysis, probably by creating perturbations in the LD membrane and facilitating ATGL's access to TAGs [30].

Several genetic models substantiate the role of ABHD5 as a potent regulator of ATGL and intracellular TAG catabolism. Consistent with reduced TAG hydrolase activities, ABHD5-KO mice show significantly increased carcass neutral lipid content with severe hepatic steatosis. In contrast to ATGL-KO mice, however, these mice die perinatally due to a severe skin barrier defect with transepidermal water loss [6]. This observation supported the notion that ABHD5 also exhibits ATGL-independent functions that promote acylceramide synthesis and the formation of the epidermal corneocyte lipid envelope [31]. In humans, mutations in the gene encoding ABHD5 are causally linked with Chanarin Dorfmann Syndrome, also designated as neutral lipid storage disease with ichthyosis (NLSD-I) [26,32]. This autosomal recessive disease has been reported in more than 100 individuals, mostly from the Mediterranean. Similar to ABHD5-KO mice, patients accumulate neutral lipids in ectopic tissues and suffer from severe ichthyosis due to a skin barrier defect [33].

Recently, two studies demonstrated that ABHD5 also binds and activates PNPLA1, a close relative of ATGL, predominantly expressed in skin keratinocytes. ABHD5 may activate a transacylase activity of PNPLA1 that could be essential for the formation of epidermal $\omega$-O-acylceramides [34,35]. Another identified ABHD5 interaction partner is PNPLA3 (also designated as adiponutrin) [36]. This is not surprising, given the high sequence homology between ATGL and PNPLA3, especially within the conserved patatin domain responsible for the interaction between ATGL and ABHD5 [19]. PNPLA3 was shown to sequester ABHD5, thereby limiting its availability for ATGL activation and, thus, lowering ATGL-dependent TAG hydrolysis, particularly in hepatocytes [36]. ABHD5 is required for PNPLA3 to localize to LDs. In contrast to the wild-type protein, PNPLA3 (I148M) mutant accumulates on the LD, sequesters ABHD5, and causes severe hepatic steatosis in mice and humans [37-39].

ABHD5 also interacts with various members of the fatty acid-binding protein (FABP) family, including adipocyte-type (A-FABP), heart-type, liver-type, intestinal-type, and epidermal-type FABP [40]. FABPs constitute a multi-protein family of nine members that share the ability to bind FAs and other hydrophobic ligands. Each member has its own characteristic tissue distribution, with A-FABP being mainly expressed in AT, macrophages, and dendritic cells [41]. In general, FABPs function as lipid chaperones, escorting lipids and dictating their biological functions. In particular, the interaction of ABHD5 and A-FABP further stimulates ABHD5-mediated ATGL activity and participates in the nuclear import of FAs to regulate the activity of nuclear receptors. However, a direct interaction of ATGL and FABP was not observed [40].

\subsection{Perilipins (PLINs)}

Both ATGL and ABHD5 bind to PLINs on the surface of LDs. In mammals, there are five perilipin genes encoding five major PLIN proteins (named in the order of their discovery as PLIN 1-5) with strong N-terminal sequence homology [42]. The N-terminal region of each PLIN harbors two characteristic 
motifs. There is an approximately 100 amino acid PAT domain (derived from perilipin, ADRP, and TIP47; the synonyms of PLIN 1, 2, and 3, respectively) localized at the N-terminus. The PAT domain is followed by a sequence of 11-mer repeats predicted to fold into an LD-anchoring, amphipathic helix. The C-terminus varies significantly between the PLIN family members [43]. Moreover, there are marked differences in their tissue distribution patterns, properties of binding to lipolytic proteins, and, thus, physiological roles.

PLIN1 is mainly expressed in the adipocytes of brown and white AT, where it coats mature, mostly unilocular, LDs. PLIN1 harbors a C-terminal binding site for ABHD5, spanning amino acid residues 382-429 [28]. Under basal conditions, PLIN1 binds and sequesters ABHD5, thereby limiting the availability of ABHD5 to interact with and stimulate ATGL and, thus, preventing accelerated lipolysis. Consistently, PLIN1-KO mice [44] and humans with frameshift mutations altering the C-terminus of PLIN1 [45,46] show unrestricted basal lipolysis and suffer from lipodystrophy.

This interaction network changes profoundly upon the stimulation of lipolysis. In times of increased energy demand (i.e., upon fasting or exercise), catecholamines bind to G-protein coupled $\beta$-adrenergic receptors on the surface of adipocytes [42]. As a result, the Gs subunit dissociates from the receptor to bind and activate adenylate cyclase, converting ATP to cAMP. Elevated cAMP concentrations activate the catalytic subunits of protein kinase A (PKA, also designated as cAMP-dependent protein kinase) by releasing the regulatory subunits from the tetrameric kinase. PKA then phosphorylates many proteins of the lipolysome. PLIN1 carries at least six serine residues within PKA consensus sequences [47], while ABHD5 has one PKA consensus sequence [48]. The phosphorylation of Ser492 and Ser517 of PLIN1 [49] and Ser239 of ABHD5 [48] is required to fully release ABHD5 from PLIN1, enabling ABHD5-mediated ATGL activation. Interestingly, ATGL was also observed to translocate to PLIN1-coated LDs following PKA activation, even though a direct interaction between ATGL and PLIN1 has been excluded [50]. The mechanism of this translocation still awaits clarification.

PLIN2 is ubiquitously expressed and represents the predominant LD-associated PLIN isoform in tissues that do not express PLIN1 or PLIN5 [42]. PLIN2 was reported to interact with both ATGL [51] and ABHD5 [52]. Nevertheless, PLIN2 only moderately controls cytosolic lipolysis for several reasons. First, PLIN2 is not phosphorylated by PKA [42] and, hence, does not respond to $\beta$-adrenergic stimulation. Second, due to structural differences in the C-terminal region, PLIN2 is less effective than PLIN1 in sequestering ABHD5 and preventing it from interacting with ATGL [53]. Thus, PLIN2 does not restrict lipolysis as efficiently as PLIN1, consistent with the relatively mild phenotype of PLIN2-KO mice on a chow diet [54].

PLIN3 also shows a broad tissue distribution but localizes more to nascent LDs, being replaced by PLIN2 when the LD size increases [42]. PLIN3 can be phosphorylated by PKA and also interacts with both ATGL and ABHD5 [51], again to a lesser extent than PLIN1. PLIN3-KO mice have unaltered AT mass but show beiging of white AT depots, with the occurrence of uncoupling protein 1 expression, multilocular adipocytes, and increased cold tolerance [55]. The knockdown of PLIN3 in AML-12 hepatoma cells similarly increases the fraction of small LDs without affecting overall TAG content [56]. Interestingly, FA and glycerol release from the inguinal white AT of PLIN3-KO mice is only increased when the mice are housed at $4{ }^{\circ} \mathrm{C}$ but not at $30{ }^{\circ} \mathrm{C}$ [55]. This might indicate that PLIN3 controls stimulated lipolysis more strongly than basal lipolysis. Whether and how its interactions with ATGL and ABHD5 are involved therein still need to be addressed.

PLIN4 is mainly expressed in white AT, and to lesser degree in skeletal muscle and the heart [57]. It shows a strong structural divergence from the other PLIN isoforms due to (i) an extended sequence of imperfect 11-mer repeats giving rise to an amphipathic helix of exceptional length [58] and (ii) the absence of the PAT domain [59]. PLIN4 preferentially localizes to LDs enriched in cholesteryl esters (CEs) rather than TAGs [42]. Due to its strong interaction with neutral lipids, yet weak interaction with lipid bilayers in vitro, PLIN4 is believed to directly contact the LD core and substitute the phospholipid coating [58]. Possible interactions between PLIN4 and ATGL or ABHD5 have not been investigated to our knowledge. PLIN4-KO mice have unaltered AT morphology and function, yet exhibit reduced 
cardiac TAG content [60]. However, PLIN5 expression is concomitantly reduced in these hearts [60], making it difficult to dissect the individual role of PLIN4 in controlling the lipolysome.

PLIN5 is mainly present in tissues with high oxidative capacity including skeletal muscle, heart, brown AT, and liver [42]. PLIN5-KO mice exhibit reduced TAG content in these tissues compared to their wild-type littermates [61-64]. Equivalent to PLIN1 in white AT, PLIN5 strongly restricts LD turnover in oxidative tissues. However, the mechanism appears to be different than it is for PLIN1. Granneman et al. [50] reported that the C-terminal half of PLIN5 carries overlapping binding sites for ATGL and ABHD5 spanning amino acids 200-453. Fluorescence imaging revealed that PLIN5 overexpression recruits both ATGL and ABHD5 to the LD surface. However, the interaction between PLIN5 and ATGL or ABHD5 is mutually exclusive, meaning that one molecule of PLIN5 can either bind ATGL or ABHD5 but not both proteins simultaneously [50]. Therefore, the authors concluded that ATGL and ABHD5 can no longer interact with each other when they are recruited to PLIN5-coated LDs; thus, basal lipolysis is attenuated.

PLIN5 carries at least one serine residue (Ser155) within a PKA consensus motif and additional phosphorylation sites for other kinases [65,66]. Pollak et al. [65] demonstrated that mutating Ser155 to an alanine residue strongly attenuates stimulated lipolysis in the heart, indicating that PKA-mediated PLIN5 phosphorylation promotes lipolysis. Thus, it is tempting to speculate that PLIN5, similarly to PLIN1, releases ABHD5 upon phosphorylation, but experimental evidence is still missing. The characteristics of phosphorylated PLIN5's binding to ATGL (and HSL) need to be investigated.

\subsection{G0/G1 Switch Gene 2 (GOS2)}

In 2010, the hypoxia-inducible protein G0S2 was identified as an ATGL inhibitor [67]. G0S2 is mainly expressed in AT and its expression increases upon adipogenesis [68]. The mechanism of ATGL inhibition requires the interaction of the hydrophobic linker domain of G0S2 with the patatin domain of ATGL [67]. The inhibitory function of GOS2 on ATGL was confirmed using transgenic animal models overexpressing G0S2 in adipocytes or cardiomyocytes causing TAG accumulation in respective cells $[69,70]$. By contrast, the G0S2-KO phenotype is relatively mild, probably due to the low G0S2 transcript levels found in most tissues. The highest G0S2 mRNA levels are observed in AT and, accordingly, G0S2-KO mice exhibit increased lipolysis, decreased AT mass, and resistance to diet-induced obesity when fed a high-fat diet $[7,8]$.

Similarly to ABHD5, G0S2 also exerts ATGL-independent pleiotropic functions. It specifically binds to the oxidative phosphorylation complex V (ATP synthase) to increase ATP production rates, a process that is hypothesized to circumvent energy depletion, especially under hypoxic conditions [71]. In bone marrow hematopoietic cells, G0S2 was shown to interact with nucleolin (NCL) to retain this typically nucleolar RNA-binding protein in the cytosol [72]. As a consequence, NCL cannot exert its otherwise pro-proliferative actions, and cells stay in a quiescent state. Another G0S2 interaction partner is B-Cell CLL/Lymphoma 2 ( $\mathrm{Bcl} 2)$, an anti-apoptotic protein [73]. Whether and how oxidative phosphorylation, cell cycle progression, and apoptosis "crosstalk" with lipolysis via G0S2 remains to be elucidated.

\subsection{Hypoxia-Inducible LD-Associated Protein (HILPDA)}

Recently, HILPDA (also designated as hypoxia-inducible gene-2, HIG-2) was identified as a second ATGL inhibitor. HILPDA is structurally similar to G0S2, is ubiquitously expressed upon hypoxia, and localizes to the LD [74-76]. HILPDA directly binds and inhibits ATGL in vitro [75,77]. The contact region between HILPDA and ATGL was mapped to the hydrophobic N-terminus of HILPDA and the patatin domain of ATGL [77]. Consistently, deleting the amino acid region Leu7 to Gly11 in HILPDA completely abolishes its binding to ATGL [75]. Kinetic studies determining the $\mathrm{IC}_{50}$ values revealed that HILPDA is, by two orders of magnitude, less potent as an ATGL inhibitor than G0S2 [77], raising doubts as to whether it is a direct regulator of lipolysis [78]. While HILPDA overexpression or gene 
deletion affected cellular TAG content in various cancer cells and hepatocytes [74-76], no clear impact on TAG hydrolysis was observed in adipocytes [77].

\subsection{Fat-Specific Protein-27 (FSP-27)}

Another inhibitory lipolysome member is FSP-27 (also designated as cell death-inducing DNA fragment factor 40/45-like effector C, CIDEC). FSP-27 is found exclusively in white and brown AT, and its mRNA is upregulated during adipogenesis [79]. The absence of FSP-27 in mice and humans causes lipodystrophy paralleled by the occurrence of atypical, multilocular white adipocytes, and higher lipolysis rates $[9,10]$. Conversely, FSP-27 overexpression is associated with the formation of supersized LDs and neutral lipid accumulation in various cell types [79].

How FSP-27 inhibits lipolysis is not fully understood. Growing evidence suggests that FSP-27 acts on multiple levels to control LD size and TAG content. Firstly, FSP-27 was demonstrated to be enriched at LD contact sites in 3T3-L1 adipocytes, where it mediates unidirectional neutral lipid transfer from smaller to larger LDs [80]. On a molecular level, this function is regulated by a polybasic linker domain electrostatically interacting with phospholipids [81]. The FSP-27-elicited production of large, unilocular LDs involves the interaction of FSP-27 with PLIN1 [82,83]. Secondly, FSP-27 interacts with ATGL and inhibits ATGL-mediated glycerol release [84]. Unlike G0S2 and HILPDA, however, FSP-27 does not inhibit ATGL's in vitro TAG hydrolase activity [85], suggesting that FSP-27 limits ATGL's access to LDs or interferes with its interaction with ABHD5. FSP-27's inhibitory impact on lipolysis can also explain the pro-lipolytic function of growth hormone $(\mathrm{GH})$. $\mathrm{GH}$ interferes with peroxisome proliferator-activated receptor (PPAR) gamma signaling by promoting its nuclear export via PPAR gamma Ser273 phosphorylation, which, as a consequence, downregulates FSP-27 and activates lipolysis [86].

\subsection{Pigment Epithelium-Derived Factor (PEDF)}

Since its discovery as a glycoprotein secreted from cultured pigment epithelial cells, numerous follow-up studies have proved PEDF to be involved in a wide range of biological processes including angiogenesis, neuroprotection, tumor growth, and metastasis. PEDF is ubiquitously expressed and, consistent with its intrinsic leader sequence responsible for secretion, abundantly found in the plasma [87]. Interestingly, AT is a major source of circulating PEDF, and PEDF plasma concentrations are elevated in obese individuals [88].

Searching for potential PEDF receptors, Notari et al. [17] identified ATGL as a high-affinity, membrane-associated PEDF binding partner using a combination of biochemical and biophysical methods. In vitro hydrolase activity assays revealed that recombinantly expressed ATGL exhibits phospholipase activity, which can be stimulated by the addition of purified PEDF. According to these findings, extracellular PEDF would be able to exert its functions via activating membrane-bound ATGL. However, to our knowledge, the latter study remains the only one to show that ATGL localizes to the plasma membrane, while a large body of evidence suggests that ATGL primarily localizes to the cytoplasm and LDs. LD-associated ATGL also interacts with PEDF after its cellular uptake [89-91]. Several observations indicate that PEDF activates ATGL-mediated TAG hydrolysis, at least in the liver, cardiac muscle, and AT: (i) A genetic deficiency of PEDF causes hepatic TAG accumulation. This phenotype can be reversed by treating PEDF-KO hepatocytes with recombinant PEDF, unless ATGL is concomitantly inhibited [90]. PEDF is also downregulated in diet-induced hepatosteatosis [89]. (ii) Recombinant PEDF increases basal lipolysis in wild-type but not ATGL-KO AT explants [91]. (iii) Recombinant PEDF decreases the TAG content of cardiomyocytes solely in the presence of ATGL [92]. Data on the interaction regions are scarce. Mutational studies have been performed to map the regions involved in the ATGL/PEDF interaction. PEDF co-immunoprecipitates with human ATGL lacking amino acids 1-267 but not with human ATGL lacking amino acids 268-504 [89], implying that PEDF binds to the C-terminal half of ATGL. Consistent with the finding that G0S2 binds to the patatin domain of ATGL [67] located within its N-terminus, the authors observed that ATGL can simultaneously bind 
PEDF and G0S2. A 44-mer peptide derived from PEDF (Val78-Thr121) decreases cardiomyocyte TAG content to the same extent as full-length PEDF [92], suggesting that ATGL binding involves amino acid residues located between Val78 and Thr121 of PEDF. However, co-immunoprecipitation studies using different mutants are needed to prove this hypothesis.

In conclusion, PEDF likely acts as a pro-lipolytic factor by activating ATGL, although mechanistic details remain elusive. The functional contribution of extracellular PEDF provoking receptor-mediated signaling events needs to be revisited.

\subsection{Ubiquitin Regulatory X Domain-Containing Protein 8 (UBXD8)}

Olzman et al. [93] reported an interaction between ATGL and UBXD8. Mechanistically, the authors propose that UBXD8 or the segregase activity of its interaction partner p97 subunit/valosin containing protein (p97/VCP) disassembles the ATGL/ABHD5 complex. Accordingly, the overexpression of UBXD8 increases LD size and number in HeLa cells. Since UBXD8 is not found in adipocytes, it may be more relevant for the inhibition of lipolysis in non-adipose tissues. However, recent data from UBXD8-KO mice provided no evidence for a "hyperlipolytic" state [94]. By contrast, UBXD8-KO mice developed liver steatosis when fed a high-fat diet. Further gain- or loss-of-function studies are required to estimate the physiological relevance of the UBXD8/ATGL interaction.

\subsection{Golgi Brefeldin a Resistance Factor 1 (GBF1)}

GBF1 is another lipolysome member that directly interacts with ATGL via several contact regions [95]. GBF1 acts as a guanine nucleotide exchange factor for ADP-ribosylation factor 1 (ARF1), which in turn affects the coatomer protein I (COPI). The GBF1/ARF1/COPI protein ensemble mediates retrograde protein transport from the Golgi network to the ER, and cargo export from the ER [96,97]. This process apparently affects ATGL targeting to the LD surface, since the inactivation of the protein ensemble by Brefeldin A or GBF1/COPI silencing abrogates ATGL's LD association upon oleic acid treatment [95]. In both cases, ATGL accumulates in the membrane fraction, more precisely in ER exit sites. Accordingly, GBF1/COPI silencing also results in oversized LDs in HeLa cells and Drosophila melanogaster [98-100]. Whether GBF1 affects basal and/or activated lipolysis needs to be clarified.

\section{9. $14-3-3$}

14-3-3 proteins constitute a highly conserved regulatory protein family of seven isoforms affecting a large variety of cellular processes [101-103]. More than 300 different 14-3-3 interaction partners have been reported, most of which contain consensus sequences with phosphorylated serine or threonine residues. ATGL is one of these interaction partners [22]. A non-phosphorylatable ATGL mutant failed to bind 14-3-3 in vitro and exhibited decreased in vitro TAG hydrolase activity, suggesting that ATGL might be stabilized in response to $5^{\prime}$ adenosine monophosphate-activated protein kinase (AMPK) phosphorylation and 14-3-3 binding. The Caenorhabditis elegans ATGL homolog was also shown to be phosphorylated by AMPK, generating a 14-3-3 binding site, which, in contrast to the other study, sequesters ATGL away from the LD surface and decreases its activity [104]. Currently, no consistent model exists for the role of 14-3-3 in the regulation of ATGL localization, stability, or activity.

\subsection{Peroxisome Biogenesis Factor 5 (PEX5)}

Proteins of the PEX family are essential for peroxisome biogenesis and the sequestering of peroxisomal proteins from the cytoplasm to nascent peroxisomes [105]. Among those, PEX5, or peroxisome target sequence 1 receptor protein (PTS1R), which occurs predominantly in the cytoplasm, shuttles PTS1 binding peroxisomal proteins from the cytoplasm to the peroxisome $[105,106]$. Recently, PEX5 has been reported to regulate fasting-induced lipolysis by direct interaction with ATGL [107]. Using Caenorhabditis elegans, 3T3-L1 adipocytes, and mice, the authors demonstrate that peroxisome-LD interactions are enhanced upon fasting and necessary for fully activated fasting-mediated lipolysis. Apparently, fasting induced the Kinesin Family Member C3 (KIFC3)-dependent movement of 
peroxisomes towards LDs and enabled ATGL co-localization to peroxisome-LD contact points. The genetic and pharmacological inhibition of peroxisome movement prevents ATGL translocation and diminishes fasting-induced lipolysis. RNAi screening in Caenorhabditis elegans revealed PEX5 to be responsible for ATGL recruitment, and further co-immunoprecipitation and imaging studies proved the direct interaction of PEX5 and ATGL. In line with these findings, PEX5-KO mice showed reduced ATGL LD localization and reduced fasting-induced lipolysis. The simultaneous knock down of PEX5 and ABHD5 was able to lower lipolytic activity in 3T3-L1 cells, but the co-suppression of ATGL and ABHD5 yielded similar results compared to the single knock-down of ATGL or PEX5. Based on these findings and the fact that ABHD5 suppression did not alter ATGL localization on LDs, the authors concluded that PEX5 acts independently of ABHD5 on lipolysis. Although this study elegantly described a novel regulatory mechanism of lipolysis, several aspects such as the involvement of ABHD5, other LD components, and lipases have to be clarified.

\section{HSL and Its Interaction Partners}

HSL was initially described in 1964 to be an AT lipid hydrolase induced by fasting and hormones [108-110]. Although its expression is highest in white and brown AT, it is also detectable in many other tissues and cell types including cardiac and skeletal muscle, liver, kidney, pancreas, and steroidogenic tissues [111-113]. HSL exhibits a broad substrate spectrum, hydrolyzing TAGs, DAGs, MAGs [114], retinyl esters, CEs [115,116], steroid hormone FA esters [117], and even water soluble, short-chain FA ester substrates [118]. HSL shows the highest activity against sn-1,3 DAGs followed by CEs and TAGs $[16,112]$.

HSL-KO mice accumulate DAGs in AT, muscle, and the testis [119] Unlike ATGL-KO mice, HSL-KO mice do not develop cardiomyopathy or cold intolerance $[119,120]$, but male HSL-KO mice are sterile [120]. Remarkably, HSL-KO mice develop partial lipodystrophy, particular upon advanced age, which is associated with hepatosteatosis [121]. Similarly to mice, humans lacking HSL protein also accumulate DAGs in white AT and develop lipodystrophy and liver steatosis [122]. The mechanistic role of HSL in adipogenesis, AT growth, and degradation is currently poorly understood and deserves major attention.

Although HSL has been intensively studied, its crystal structure has not yet been solved. According to the current domain structure model, the $82 \mathrm{kDa}$ enzyme contains four functionally relevant domains: (1) the N-terminal domain, which is essential for HSL dimerization and serves as docking domain for protein-protein interactions [123]; (2) the C-terminal domain harboring the catalytic triad within a typical alpha/beta-hydrolase fold [124-126]; (3) the regulatory domain containing five known phosphorylation sites (mouse HSL: Ser563, Ser659, and Ser660 are phosphorylated by PKA, Ser565 by AMPK, and Ser600 by extracellular signal-regulated kinase (ERK); human HSL: Ser552, Ser649, and Ser650 are phosphorylated by PKA, Ser554 by AMPK, and Ser589 by ERK [127-132]), which regulate the localization and activity of HSL [133]; and (4) the putative lipid-binding domain [134].

Just like ATGL, HSL also requires protein-binding partners that regulate enzyme localization and activity. Several of these are shared by both lipases. (Putative) domain structures, phosphorylation sites, and interaction partners of murine HSL are shown in Figures 2 and 3.

\subsection{FABPS}

As described above, virtually all members of the FABP family interact with ABHD5 to regulate ATGL-mediated lipolysis. Two members, A-FABP and epidermal-type-FABP, also bind to HSL [135-138]. Apparently, HSL is more selective than ABHD5 for FABP binding because liver-typeand intestinal-type-FABP do not interact with the lipase [135,139]. The overexpression of fluorescently tagged HSL and A-FABP in adipocyte-like cells demonstrated that the A-FABP/HSL complex already exists under basal conditions in the cytosol and translocates to the LD surface in response to the hormonal stimulation of lipolysis [135]. 
A-FABP directly interacts with HSL at its N-terminal region from amino acids 192 to 200 [140]. In this sequence, two specific residues (His194 and Glu199) have been identified that determine the binding of HSL to A-FABP (Figure 3). Additionally, Smith et al. [137] demonstrated that the interaction is dependent on HSL phosphorylation. Mouse HSL with mutations at two PKA phosphorylation sites, Ser659 and Ser660, or at the AMPK phosphorylation site Ser565 failed to interact with A-FABP in living cells. However, incoherent reports exist on the functional consequences of the A-FABP/HSL interaction. Initial studies showed that either the co-incubation of in vitro translated HSL with purified A-FABP or the co-expression of HSL and A-FABP in CHO-cells increases the hydrolytic activity of HSL against CEs [136]. In contrast, A-FABP-KO mice exhibit decreased lipolysis in vivo and in situ [141]. Therefore, it was assumed that A-FABP prevents HSL from product inhibition by sequestering the produced FAs. Consistently, A-FABP did not alter HSL's activity against p-nitrophenyl butyrate, which was explained by the fact that FABPs do not bind the released reaction product, butyric acid [139]. Interestingly, liver-type- and intestinal-type FABP, despite not interacting with HSL, also stimulated its CE hydrolase activity [139], leading to the conclusion that physical association is not necessary for activation. However, Shen et al. [140] reported that both wild-type A-FABP and FA-binding defective A-FABP (A-FABP ${ }^{R 126 L}$ ) bind to and stimulate HSL activity in vitro. These data support a scenario where A-FABP binding to HSL leads to conformational changes in the lipase, causing enzyme activation. But this interaction was not present when another FA binding defective mutant of A-FABP $\left(\mathrm{A}-\mathrm{FABP}{ }^{\mathrm{R} 126 \mathrm{Q}}\right.$ ) was used [137]. Consistently, the presence of oleate was a prerequisite to the detection of A-FABP/HSL complexes in isothermal titration calorimetry experiments [139]. These observations led to the hypothesis that solely ligand-bound A-FABP binds to HSL to inhibit its hydrolytic activity in a negative feedback loop.

\subsection{PLINS}

The interaction of PLIN1 with HSL contributes significantly to HSL regulation upon hormonal stimulation of lipolysis. The binding of catecholamines to $\beta$-adrenergic receptors leads to the activation of adenylate cyclase and, hence, the elevation of intracellular cAMP levels. This, in turn, activates PKA, which directly phosphorylates HSL at the residues Ser563, Ser659, and Ser660. However, the modestly increased activity of phosphorylated HSL in vitro could not explain why catecholamines stimulate lipolysis up to 100-fold in adipocytes [142]. This apparent discrepancy was explained by follow-up studies showing that PKA also phosphorylates PLIN1 at multiple serine sites (rodent PLIN1 has six residues: Ser81, Ser222, Ser276, Ser433, Ser492, and Ser517; human PLIN1 has five residues: Ser81, Ser276, Ser433, Ser497, and Ser522), which causes conformational changes to strengthen its interaction with HSL. This fundamental process recruits HSL to the LD surface and enhances its substrate access for full lipolytic stimulation [143-147]. In accordance with this model, Wang et al. [148] demonstrated that the direct interaction between PLIN1 and HSL on LDs significantly increases following PKA stimulation of cells. Although the interaction of HSL and PLIN1 was verified repeatedly, the binding site(s) of HSL to PLIN1 is (are) still debatable [148,149]. Wang et al. [148] showed an interaction of the lipase within the highly conserved N-terminal PAT domain, while Shen et al. [149] identified HSL binding sites on the N-terminus outside of the PAT region and on the C-terminus. These sites not only overlap with sequences that have been implicated in LD barrier function [150], but also with sequences that interact with ABHD5 [28,52], suggesting that the interaction of HSL with PLIN1 facilitates multiple functions including the recruitment of HSL to LDs as well as the regulation of lipolysis [149].

Wang et al. [148] further demonstrated that HSL also interacts with PLIN2, 3, and 5 (PLIN4 was not investigated) via their N-terminal PAT domains to regulate the localization of HSL to LDs in non-adipose cells. In contrast to PLIN1, PLIN2, 3, and 5 already interact with HSL under basal conditions, and their binding to the lipase is either reduced (PLIN2) or unchanged (PLIN3, 5) upon PKA stimulation, suggesting the involvement of additional regulatory mechanisms to control lipolysis [148]. 


\subsection{Vimentin (VIM)}

VIM is an intermediate filament protein that is part of the cytoskeletal network. Additionally, it is located on LDs under both basal and lipolysis-stimulated conditions [151]. VIM binds to HSL, and this interaction is controlled by hormones. PKA stimulates, while insulin inhibits, VIM binding to HSL [152]. Notably, VIM was also found to interact with $\beta_{3}$-adrenergic receptors to transduce the lipolytic signal via the ERK pathway in response to catecholamines. The pharmacological disruption of VIM filaments blocks ERK activation and reduces CL 316,243 stimulated lipolysis in adipocytes, but not forskolin-stimulated lipolysis, which is mainly mediated by PKA activation [153]. Disruption of the endogenous VIM intermediate filament network impairs LD formation and TAG accumulation in 3T3-L1 adipocytes [154]. Consistently, VIM-KO mice exhibit smaller adipocytes [152]. Furthermore, adipocytes isolated from VIM-KO mice show both reduced HSL translocation to the LDs and a decreased lipolytic response to isoproterenol [152]. These data suggest a close functional relationship between lipolysis and the cytoskeleton, which requires mechanistic validation.

\subsection{Cavin-1}

Another HSL interaction partner is cavin-1 (also designated as polymerase I and transcript release factor, PTRF) which is a major structural component of caveolae [155]. Plasma membrane invaginations in the form of caveolae are found in most mammalian cell types and are particularly abundant in white adipocytes. Caveolae are believed to be involved in the uptake and storage of FAs and their release [156]. A deficiency of cavin-1 in mice or humans results in dysregulated lipid metabolism, including the impaired hydrolysis and synthesis of TAGs, leading to lipodystrophy [157-160].

Proteins involved in lipolysis such as HSL and PLIN1 are also present in caveolae, maintaining a coordinated TAG turnover [161]. Hence, Aboulaich and colleagues [162] demonstrated a direct interaction of cavin-1 with HSL showing that insulin treatment triggers cavin-1 and HSL co-migration from the plasma membrane to the cytosol in primary human adipocytes. A recent study further showed that acetylation of cavin-1 promotes interaction with HSL and recruits the lipase to the caveolae to increase lipolysis [163]. Besides these direct effects of cavin-1 to control lipolysis via HSL translocation, cavin-1 might further modulate HSL-mediated lipolytic activity indirectly via the regulation of PLIN1 phosphorylation. As previously shown, PLIN1 phosphorylation is required for HSL activity (see above) [145]. Accordingly, the phosphorylation of PLIN1 is blunted in cavin-1-KO mice, resulting in impaired stimulated lipolysis [160], which might be partly due to the reduced lipolytic activity of HSL, suggesting that cavin-1 is a critical regulator of HSL activity at caveolae.

\subsection{Carbohydrate Response Element Binding Protein (ChREBP)}

ChREBP is a glucose-activated transcription factor that regulates de novo lipogenesis (DNL) in multiple tissues including the liver and AT [164]. In humans, the expression of ChREBP and adipose DNL are positively associated with insulin sensitivity $[165,166]$. Recently, an exciting study demonstrated a direct interaction between HSL and ChREBP regulating insulin signaling in white adipocytes [167]. Thereby, HSL retains ChREBP in the cytoplasm, preventing its nuclear translocation and subsequent transcriptional induction of target genes such as the FA elongase ELOVL6, an enzyme catalyzing the elongation of palmitic acid to stearic acid, which can be further desaturated into oleic acid. By contrast, the partial inhibition of HSL, which was shown to improve insulin sensitivity in murine AT and human adipocytes $[167,168]$, increases ELOVL6 expression. As a consequence, increased amounts of oleic acid are incorporated into phospholipids. This change in phospholipid composition alters plasma membrane properties and improves insulin signal transduction.

Morigny et al. [167] further showed that an enzymatically inactive form of HSL represses ChREBP activity as well, indicating that the protein-protein interaction depends on the presence of HSL but not on its lipolytic activity. However, it is still elusive as to which part of HSL binds to ChREBP and whether the phosphorylation of the lipase modifies their interaction. 


\subsection{Microtubule-Associated Proteins 1A/1B Light Chain 3B (LC3)}

LC3 is a crucial component of autophagosomes. Besides its pro-autophagic activity, LC3 has been recently implicated in regulating lipolysis via modulating ATGL and HSL activity [169]. Both lipases contain multiple LC3-interacting region (LIR) motifs in their primary sequences and co-localize with LC3 in response to cold exposure as well as in response to rapamycin-induced autophagy with LDs in brown AT and the liver. In addition, cold exposure also enriches these lipases on the cytoplasmic site of LC3/autophagosomes. Using co-immunoprecipitation, Martinez-Lopez et al. [169] confirmed a direct interaction of HSL with LC3 that increases by inducing autophagy. Although not investigated, LC3 most likely binds to the N-terminal region of HSL, since five of the seven LIR motifs are located at the N-terminus. Furthermore, mutating a single LIR motif of ATGL resulted in the mislocalization of ATGL and neutral lipid accumulation in an adipocyte cell line, suggesting that the LC3-ATGL interaction controls the recruitment of ATGL to LDs and, consequently, its lipolytic activity [169]. Together, the interaction of LC3 with ATGL and HSL might coordinate lipolysis and (lipo-)autophagy.

\subsection{Steroidogenic Acute Regulatory Protein (StAR)}

StAR is a critical regulator of steroid biosynthesis by facilitating the intracellular transfer of cholesterol from the outer to the inner mitochondrial membrane [170]. HSL, as a main CE hydrolase, provides cholesterol for steroidogenesis [120]. Hence, Shen et al. [171] demonstrated a direct interaction of HSL with the N-terminal and central regions of StAR. Consequently, HSL-mediated CE hydrolase activity increases in the presence of StAR, suggesting that their interaction results in conformational changes of the lipase that either enable efficient substrate access or reduce product inhibition. Furthermore, the overexpression of HSL in adrenal cells increases mitochondrial cholesterol content when StAR expression is induced, implying that both proteins form a functional complex to promote the release and transfer of cholesterol from cytoplasmic LDs to mitochondria for steroidogenesis.

\section{MGL and Its Interaction Partners}

MGL is the third lipase within the lipolysome hydrolyzing MAGs, thereby releasing glycerol and a FA. It belongs to the alpha/beta hydrolase protein family, exhibiting a typical alpha/beta-hydrolase fold with a GXSXG motif, and a Ser-Asp-His catalytic triad [172]. In 2010, the three-dimensional structure of human MGL was solved by X-ray diffraction by two independent groups $[173,174]$. The protein has a cap domain that covers the structurally conserved $\beta$-sheet and the active site that resides at the end of an unusually large hydrophobic tunnel. Additionally, human MGL provides an exit hole for the release of glycerol after hydrolysis that is located at the level of the catalytic triad. MGL is ubiquitously expressed among tissues, with slightly different molecular sizes [175]. The enzyme exhibits high hydrolytic activity against MAGs [176]; however, it was also shown to hydrolyze prostaglandin glycerol esters [177] and FA ethyl esters [178].

MGL-KO mice accumulate different MAG species in various tissues and are resistant to diet-induced obesity and protected from the development of liver steatosis [179-181]. In addition to its role within the lipolytic cascade, MGL is particularly important in the endocannabinoid system. It degrades 2-arachidonoyl glycerol (2-AG), the most abundant endogenous agonist of cannabinoid receptors (CBRs) [182]. The accumulation of 2-AG in MGL-KO mice provokes massive CBR desensitization and resistance to exogenous CBR agonists [183-185].

In contrast to the large number of published interaction partners of ATGL and HSL, only a few reports have addressed the regulation of MGL activity or expression by protein-protein interactions, but none of them have investigated a potential regulatory role in lipolysis. Based on automated yeast two hybrid interaction mating, chromogranin B (CHGB), a glycoprotein involved in vesicle sorting [186], was proposed to be a putative MGL binding partner [187]. However, functional analysis of this interaction is still elusive. 
More recently, a negative correlation of Staphylococcal nuclease and tudor domain containing 1 (SND1) with MGL has been found in cancer cells [188], implying that SND1 and MGL influence each other's expression. SND1 is a multifactorial protein acting as an oncogene in multiple cancers [189]. MGL was also shown to be involved in carcinogenesis by either promoting tumorigenesis or functioning as a tumor suppressor, depending on the tumor type $[190,191]$. The interaction of SND1 with MGL results in the ubiquitination and subsequent proteasomal degradation of the lipase, which eventually promotes the tumorigenic proliferation of hepatocellular carcinoma [188].

Another recent study demonstrated that MGL enhances prostate cancer metastasis in vitro and in vivo, dependent on epidermal FABP. Overexpression of MGL significantly increased PPAR gamma activity to promote a metastatic phenotype, while epidermal FABP knockdown attenuated PPAR gamma even in cells overexpressing MGL. However, functional studies to investigate whether direct protein-protein interaction is needed for this process have not been carried out [192]. Interestingly, other studies demonstrated that HSL and ABHD5 interact only with distinct FABPs. Therefore, it would be interesting to investigate whether one or more FABPs interact with MGL to alter its hydrolytic activity. An overview of human MGL's domain structure and putative interaction partners is shown in Figures 2 and 3.

\section{Conclusions and Outlook}

Protein-protein interactions are of fundamental importance to the integrity of biological networks. Hence, viewing intracellular lipolysis simply as three lipases acting sequentially to hydrolyze TAGs is far too simplistic. As summarized in this review, these lipases interact with a broad set of regulatory, accessory, and scaffolding proteins. Many of these proteins (e.g., FABPs, PLINs, and LC3) were reported to either directly or indirectly interact with both ATGL and HSL, suggesting that the lipolysome may in fact act as a macromolecular complex (Figure 2). However, the temporal and spatial dynamics of these interactions remain to be determined. Other interactions (e.g., those of ATGL/HSL with UBXD-8, cavin-1, or StAR) and their physiological consequences still need to be validated by complementary methods in order to obtain a more profound and reliable picture of the lipolysome.

To date, a high number of interaction partners have been described for ATGL and HSL, but only a few have been described for MGL. Since ATGL is the rate limiting lipase in TAG hydrolysis, it could be assumed that tight regulation of the first step of lipolysis is probably more efficient in fine-tuning lipolysis under various physiological conditions, which has attracted many studies on this specific lipase over the last decade.

In addition to such studies on the physiological role of lipolysis and its complex regulation, a quantitative description of the intricate reaction processes of TAG hydrolysis is of utmost importance. Recent advances in the biochemical characterization of the lipolytic pathway, the availability of mutant mouse lines for all lipases, and the discovery of specific lipase inhibitors $([193,194]$ and reviewed in [195]) represent a highly topical opportunity to aim for a quantitative description of lipolysis and its regulatory network. Developing a mathematical model of lipolysis will help to accurately dissect the relative contribution of the individual lipases to each step of acylglycerol hydrolysis.

A deeper understanding of the interactome governing lipolysis might also pave new ways for drug discovery. In recent years, dozens of small molecules or peptides targeting protein-protein interactions have reached clinical development, predominantly for the treatment of cancer [196]. Likewise, modifying specific interactions within the lipolysome pharmacologically might represent a powerful strategy to combat diseases associated with dysregulated neutral lipid catabolism.

Author Contributions: Conceptualization, P.H. and G.S.; writing—original draft preparation, P.H., U.T., P.K., and G.S.; writing-review and editing, P.H., U.T., R.S., P.K., and G.S.; Figure design, P.H. and R.S.; supervision, G.S. All authors have read and agreed to the published version of the manuscript.

Funding: This research was funded by the following: FWF Stand-alone projects P28882-B21 and P31638-B34 as well as by SFB F73. 
Acknowledgments: The authors would like to thank Rudolf Zechner for discussions and critically reviewing the manuscript. Open Access is funded by the Austrian Science Fund (FWF).

Conflicts of Interest: The authors declare no conflicts of interest.

\section{Abbreviations}

2-AG

AMPK

ABHD5

ADP

ADRP

ARF-1

AT

ATGL

ATP

$\mathrm{Bcl} 2$

cAMP

CBRs

CE

CGI-58

CHGB

ChREBP

CIDEC

CL 316,243

COPI

DAG

DNL

ELOVL6;

ER

ERK

FA

FABP

FSP-27

G0S2

GBF1

$\mathrm{GH}$

HIG-2

HILPDA

HSL

$\mathrm{IC}_{50}$

iPLA2-zeta

KIFC3

$\mathrm{KO}$

LC3

LC3-interacting region

LD

MAG

MGL

NCL

NLSD-M/-I

p97/VCP

PAT

PEDF

PEX5 2-arachidonoyl glycerol

5 ' adenosine monophosphate-activated protein kinase

alpha/beta-hydrolase domain containing protein 5

adenosine-diphosphate

adipose differentiation related protein

ADP-ribosylation factor 1

adipose tissue

adipose triglyceride lipase

adenosine-triphosphate

B-Cell CLL/Lymphoma 2

cyclic adenosine monophosphate

cannabinoid receptors

cholesteryl ester

comparative gene identification-58

chromogranin B

carbohydrate response element binding protein

cell death-inducing DNA fragment factor 40/45-like effector C

$\beta_{3}$ adrenoceptor agonist

coatomer protein I

diacylglycerol

de novo lipogenesis

elongase of long chain fatty acids family 6

endoplasmic reticulum

extracellular signal-regulated kinase

fatty acid

fatty acid-binding protein

fat-specific protein-27

G0/G1 switch gene 2

Golgi Brefeldin A resistance factor 1

growth hormone

hypoxia-inducible gene- 2

hypoxia-inducible LD-associated protein

hormone-sensitive lipase

half maximal inhibitory concentration

$\mathrm{Ca}^{2+}$-independent phospholipase A2-zeta

Kinesin Family Member C3

knockout

microtubule-associated proteins 1A/1B light chain 3B

LC3-interacting region

lipid droplet

monoacylglycerol

MAG lipase

nucleolin

neutral lipid storage disease with myopathy/with ichthyosis

partner $\mathrm{p} 97$ subunit/valosin containing protein

perilipin/ADRP/TIP47

pigment epithelium-derived factor

peroxisome biogenesis factor 5 


$\begin{array}{ll}\text { PKA } & \text { protein kinase A } \\ \text { PLIN } & \text { perilipin } \\ \text { PNPLA } & \text { patatin-like phospholipase domain containing } \\ \text { PPAR } & \text { peroxisome proliferator-activated receptor } \\ \text { PTRF } & \text { polymerase I and transcript release factor } \\ \text { PTS1R } & \text { peroxisome target sequence } 1 \text { receptor protein } \\ \text { RNA } & \text { ribonucleic acid } \\ \text { RNAi } & \text { RNA interference } \\ \text { SND1 } & \text { Staphylococcal nuclease and tudor domain containing } 1 \\ \text { StAR } & \text { steroidogenic acute regulatory protein } \\ \text { TAG } & \text { triacylglycerol } \\ \text { TIP-47 } & \text { tail-interacting protein of } 47 \text { kDa } \\ \text { UBXD8 } & \text { ubiquitin regulatory } X \text { domain-containing protein } 8 \\ \text { VIM } & \text { Vimentin }\end{array}$

\section{References}

1. Zechner, R.; Madeo, F.; Kratky, D. Cytosolic lipolysis and lipophagy: Two sides of the same coin. Nat. Rev. Mol. Cell Biol. 2017, 18, 671-684. [CrossRef] [PubMed]

2. Singh, R.; Kaushik, S.; Wang, Y.; Xiang, Y.; Novak, I.; Komatsu, M.; Tanaka, K.; Cuervo, A.M.; Czaja, M.J. Autophagy regulates lipid metabolism. Nature 2009, 458, 1131-1135. [CrossRef] [PubMed]

3. Wahli, W.; Michalik, L. PPARs at the crossroads of lipid signaling and inflammation. Trends Endocrinol. Metab. 2012, 23, 351-363. [CrossRef] [PubMed]

4. Papackova, Z.; Cahova, M. Fatty Acid Signaling: The New Function of Intracellular Lipases. Int. J. Mol. Sci. 2015, 16, 3831-3855. [CrossRef] [PubMed]

5. Schreiber, R.; Xie, H.; Schweiger, M. Of mice and men: The physiological role of adipose triglyceride lipase (ATGL). Biochim. Biophys. Acta-Mol. Cell Biol. Lipids 2019, 1864, 880-899. [CrossRef]

6. Radner, F.P.W.; Streith, I.E.; Schoiswohl, G.; Schweiger, M.; Kumari, M.; Eichmann, T.O.; Rechberger, G.; Koefeler, H.C.; Eder, S.; Schauer, S.; et al. Growth retardation, impaired triacylglycerol catabolism, hepatic steatosis, and lethal skin barrier defect in mice lacking comparative gene identification-58 (CGI-58). J. Biol. Chem. 2010, 285, 7300-7311. [CrossRef]

7. Zhang, X.; Xie, X.; Heckmann, B.L.; Saarinen, A.M.; Czyzyk, T.A.; Liu, J. Targeted disruption of G0/G1 switch gene 2 enhances adipose lipolysis, alters hepatic energy balance, and alleviates high-fat diet-induced liver steatosis. Diabetes 2014, 63, 934-946. [CrossRef]

8. $\quad$ El-Assaad, W.; El-Kouhen, K.; Mohammad, A.H.; Yang, J.; Morita, M.; Gamache, I.; Mamer, O.; Avizonis, D.; Hermance, N.; Kersten, S.; et al. Deletion of the gene encoding G0/G1 switch protein 2 (G0s2) alleviates high-fat-diet-induced weight gain and insulin resistance, and promotes browning of white adipose tissue in mice. Diabetologia 2015, 58, 149-157. [CrossRef]

9. Rubio-Cabezas, O.; Puri, V.; Murano, I.; Saudek, V.; Semple, R.K.; Dash, S.; Hyden, C.S.S.; Bottomley, W.; Vigouroux, C.; Magré, J.; et al. Partial lipodystrophy and insulin resistant diabetes in a patient with a homozygous nonsense mutation in CIDEC. EMBO Mol. Med. 2009, 1, 280-287. [CrossRef]

10. Nishino, N.; Tamori, Y.; Tateya, S.; Kawaguchi, T.; Shibakusa, T.; Mizunoya, W.; Inoue, K.; Kitazawa, R.; Kitazawa, S.; Matsuki, Y.; et al. FSP27 contributes to efficient energy storage in murine white adipocytes by promoting the formation of unilocular lipid droplets. J. Clin. Investig. 2008, 118, 2808-2821. [CrossRef]

11. Egloff, M.-P.; Sarda, L.; Verger, R.; Cambillau, C.; Tilbeurgh, H. Van Crystallographic study of the structure of colipase and of the interaction with pancreatic lipase. Protein Sci. 1995, 4, 44-57. [CrossRef] [PubMed]

12. Coleman, R.A. It takes a village: Channeling fatty acid metabolism and triacylglycerol formation via protein interactomes. J. Lipid Res. 2019, 60, 490-497. [CrossRef] [PubMed]

13. Zimmermann, R.; Strauss, J.G.; Haemmerle, G.; Schoiswohl, G.; Birner-Gruenberger, R.; Riederer, M.; Lass, A.; Neuberger, G.; Eisenhaber, F.; Hermetter, A.; et al. Fat mobilization in adipose tissue is promoted by adipose triglyceride lipase. Science 2004, 306, 1383-1386. [CrossRef] [PubMed]

14. Villena, J.A.; Roy, S.; Sarkadi-Nagy, E.; Kim, K.-H.; Sul, H.S. Desnutrin, an adipocyte gene encoding a novel patatin domain-containing protein, is induced by fasting and glucocorticoids: Ectopic expression of desnutrin increases triglyceride hydrolysis. J. Biol. Chem. 2004, 279, 47066-47075. [CrossRef] 
15. Jenkins, C.M.; Mancuso, D.J.; Yan, W.; Sims, H.F.; Gibson, B.; Gross, R.W. Identification, cloning, expression, and purification of three novel human calcium-independent phospholipase A2 family members possessing triacylglycerol lipase and acylglycerol transacylase activities. J. Biol. Chem. 2004, 279, 48968-48975. [CrossRef]

16. Eichmann, T.O.; Kumari, M.; Haas, J.T.; Farese, R.V.; Zimmermann, R.; Lass, A.; Zechner, R. Studies on the substrate and stereo/regioselectivity of adipose triglyceride lipase, hormone-sensitive lipase, and diacylglycerol-O-acyltransferases. J. Biol. Chem. 2012, 287, 41446-41457. [CrossRef]

17. Notari, L.; Baladron, V.; Aroca-Aguilar, J.D.; Balko, N.; Heredia, R.; Meyer, C.; Notario, P.M.; Saravanamuthu, S.; Nueda, M.-L.; Sanchez-Sanchez, F.; et al. Identification of a lipase-linked cell membrane receptor for pigment epithelium-derived factor. J. Biol. Chem. 2006, 281, 38022-38037. [CrossRef]

18. Taschler, U.; Schreiber, R.; Chitraju, C.; Grabner, G.F.; Romauch, M.; Wolinski, H.; Haemmerle, G.; Breinbauer, R.; Zechner, R.; Lass, A.; et al. Adipose triglyceride lipase is involved in the mobilization of triglyceride and retinoid stores of hepatic stellate cells. Biochim. Biophys. Acta-Mol. Cell Biol. Lipids 2015, 1851, 937-945. [CrossRef]

19. Cornaciu, I.; Boeszoermenyi, A.; Lindermuth, H.; Nagy, H.M.; Cerk, I.K.; Ebner, C.; Salzburger, B.; Gruber, A.; Schweiger, M.; Zechner, R.; et al. The minimal domain of adipose triglyceride lipase (ATGL) ranges until leucine 254 and can be activated and inhibited by CGI-58 and G0S2, respectively. PLoS ONE 2011, 6, e26349. [CrossRef]

20. Schweiger, M.; Schoiswohl, G.; Lass, A.; Radner, F.P.W.; Haemmerle, G.; Malli, R.; Graier, W.; Cornaciu, I.; Oberer, M.; Salvayre, R.; et al. The C-terminal region of human adipose triglyceride lipase affects enzyme activity and lipid droplet binding. J. Biol. Chem. 2008, 283, 17211-17220. [CrossRef]

21. Xie, X.; Langlais, P.; Zhang, X.; Heckmann, B.L.; Saarinen, A.M.; Mandarino, L.J.; Liu, J. Identification of a novel phosphorylation site in adipose triglyceride lipase as a regulator of lipid droplet localization. Am. J. Physiol. Endocrinol. Metab. 2014, 306, E1449-E1459. [CrossRef] [PubMed]

22. Ahmadian, M.; Abbott, M.J.; Tang, T.; Hudak, C.S.S.; Kim, Y.; Bruss, M.; Hellerstein, M.K.; Lee, H.-Y.; Samuel, V.T.; Shulman, G.I.; et al. Desnutrin/ATGL is regulated by AMPK and is required for a brown adipose phenotype. Cell Metab. 2011, 13, 739-748. [CrossRef] [PubMed]

23. Haemmerle, G.; Lass, A.; Zimmermann, R.; Gorkiewicz, G.; Meyer, C.; Rozman, J.; Heldmaier, G.; Maier, R.; Theussl, C.; Eder, S.; et al. Defective lipolysis and altered energy metabolism in mice lacking adipose triglyceride lipase. Science 2006, 312, 734-737. [CrossRef] [PubMed]

24. Schreiber, R.; Diwoky, C.; Schoiswohl, G.; Feiler, U.; Wongsiriroj, N.; Abdellatif, M.; Kolb, D.; Hoeks, J.; Kershaw, E.E.; Sedej, S.; et al. Cold-Induced Thermogenesis Depends on ATGL-Mediated Lipolysis in Cardiac Muscle, but Not Brown Adipose Tissue. Cell Metab. 2017, 26, 753-763.e7. [CrossRef]

25. Schreiber, R.; Hofer, P.; Taschler, U.; Voshol, P.J.; Rechberger, G.N.; Kotzbeck, P.; Jaeger, D.; Preiss-Landl, K.; Lord, C.C.; Brown, J.M.; et al. Hypophagia and metabolic adaptations in mice with defective ATGL-mediated lipolysis cause resistance to HFD-induced obesity. Proc. Natl. Acad. Sci. USA 2015, 112, 13850-13855. [CrossRef]

26. Fischer, J.; Lefèvre, C.; Morava, E.; Mussini, J.-M.; Laforêt, P.; Negre-Salvayre, A.; Lathrop, M.; Salvayre, R. The gene encoding adipose triglyceride lipase (PNPLA2) is mutated in neutral lipid storage disease with myopathy. Nat. Genet. 2007, 39, 28-30. [CrossRef]

27. Lass, A.; Zimmermann, R.; Haemmerle, G.; Riederer, M.; Schoiswohl, G.; Schweiger, M.; Kienesberger, P.; Strauss, J.G.; Gorkiewicz, G.; Zechner, R. Adipose triglyceride lipase-mediated lipolysis of cellular fat stores is activated by CGI-58 and defective in Chanarin-Dorfman Syndrome. Cell Metab. 2006, 3, 309-319. [CrossRef]

28. Subramanian, V.; Rotlienberg, A.; Gomez, C.; Cohen, A.W.; Garcia, A.; Bhattacharyya, S.; Shapiro, L.; Dolios, G.; Wang, R.; Lisanti, M.P.; et al. Perilipin A mediates the reversible binding of CGI-58 to lipid droplets in 3T3-L1 adipocytes. J. Biol. Chem. 2004, 279, 42062-42071. [CrossRef]

29. Gruber, A.; Cornaciu, I.; Lass, A.; Schweiger, M.; Poeschl, M.; Eder, C.; Kumari, M.; Schoiswohl, G.; Wolinski, H.; Kohlwein, S.D.; et al. The N-terminal region of comparative gene identification-58 (CGI-58) is important for lipid droplet binding and activation of adipose triglyceride lipase. J. Biol. Chem. 2010, 285, 12289-12298. [CrossRef]

30. Sanders, M.A.; Zhang, H.; Mladenovic, L.; Tseng, Y.Y.; Granneman, J.G. Molecular Basis of ABHD5 Lipolysis Activation. Sci. Rep. 2017, 7, 1-13. [CrossRef] 
31. Grond, S.; Radner, F.P.W.; Eichmann, T.O.; Kolb, D.; Grabner, G.F.; Wolinski, H.; Gruber, R.; Hofer, P.; Heier, C.; Schauer, S.; et al. Skin Barrier Development Depends on CGI-58 Protein Expression during Late-Stage Keratinocyte Differentiation. J. Investig. Dermatol. 2017, 137, 403-413. [CrossRef] [PubMed]

32. Lefèvre, C.; Jobard, F.; Caux, F.; Bouadjar, B.; Karaduman, A.; Heilig, R.; Lakhdar, H.; Wollenberg, A.; Verret, J.L.; Weissenbach, J.; et al. Mutations in CGI-58, the gene encoding a new protein of the esterase/lipase/thioesterase subfamily, in Chanarin-Dorfman syndrome. Am. J. Hum. Genet. 2001, 69, 1002-1012. [CrossRef] [PubMed]

33. Schweiger, M.; Lass, A.; Zimmermann, R.; Eichmann, T.O.; Zechner, R. Neutral lipid storage disease: Genetic disorders caused by mutations in adipose triglyceride lipase/PNPLA2 or CGI-58/ABHD5. Am. J. Physiol. Endocrinol. Metab. 2009, 297, E289-E296. [CrossRef] [PubMed]

34. Kien, B.; Grond, S.; Haemmerle, G.; Lass, A.; Eichmann, T.O.; Radner, F.P.W. ABHD5 stimulates PNPLA1-mediated -O-acylceramide biosynthesis essential for a functional skin permeability barrier. J. Lipid Res. 2018, 59, 2360-2367. [CrossRef] [PubMed]

35. Ohno, Y.; Nara, A.; Nakamichi, S.; Kihara, A. Molecular mechanism of the ichthyosis pathology of Chanarin-Dorfman syndrome: Stimulation of PNPLA1-catalyzed $\omega$-O-acylceramide production by ABHD5. J. Dermatol. Sci. 2018, 92, 245-253. [CrossRef]

36. Wang, Y.; Kory, N.; BasuRay, S.; Cohen, J.C.; Hobbs, H.H. PNPLA3, CGI-58, and Inhibition of Hepatic Triglyceride Hydrolysis in Mice. Hepatology 2019, 69, 2427-2441. [CrossRef]

37. Romeo, S.; Kozlitina, J.; Xing, C.; Pertsemlidis, A.; Cox, D.; Pennacchio, L.A.; Boerwinkle, E.; Cohen, J.C.; Hobbs, H.H. Genetic variation in PNPLA3 confers susceptibility to nonalcoholic fatty liver disease. Nat. Genet. 2008, 40, 1461-1465. [CrossRef]

38. Li, J.Z.; Huang, Y.; Karaman, R.; Ivanova, P.T.; Brown, H.A.; Roddy, T.; Castro-Perez, J.; Cohen, J.C.; Hobbs, H.H. Chronic overexpression of PNPLA3 I148M in mouse liver causes hepatic steatosis. J. Clin. Investig. 2012, 122, 4130-4144. [CrossRef]

39. Smagris, E.; BasuRay, S.; Li, J.; Huang, Y.; Lai, K.-M.V.; Gromada, J.; Cohen, J.C.; Hobbs, H.H. Pnpla3I148M knockin mice accumulate PNPLA3 on lipid droplets and develop hepatic steatosis. Hepatology 2015, 61, 108-118. [CrossRef]

40. Hofer, P.; Boeszoermenyi, A.; Jaeger, D.; Feiler, U.; Arthanari, H.; Mayer, N.; Zehender, F.; Rechberger, G.; Oberer, M.; Zimmermann, R.; et al. Fatty acid-binding proteins interact with comparative gene identification-58 linking lipolysis with lipid ligand shuttling. J. Biol. Chem. 2015, 290, 18438-18453. [CrossRef]

41. Furuhashi, M.; Hotamisligil, G.S. Fatty acid-binding proteins: Role in metabolic diseases and potential as drug targets. Nat. Rev. Drug Discov. 2010, 7, 489-503. [CrossRef] [PubMed]

42. Sztalryd, C.; Brasaemle, D.L. The perilipin family of lipid droplet proteins: Gatekeepers of intracellular lipolysis. Biochim. Biophys. Acta-Mol. Cell Biol. Lipids 2017, 1862, 1221-1232. [CrossRef] [PubMed]

43. Sztalryd, C.; Kimmel, A.R. Perilipins: Lipid droplet coat proteins adapted for tissue-specific energy storage and utilization, and lipid cytoprotection. Biochimie 2014, 96, 96-101. [CrossRef] [PubMed]

44. Tansey, J.T.; Sztalryd, C.; Gruia-Gray, J.; Roush, D.L.; Zee, J.V.; Gavrilova, O.; Reitman, M.L.; Deng, C.X.; Li, C.; Kimmel, A.R.; et al. Perilipin ablation results in a lean mouse with aberrant adipocyte lipolysis, enhanced leptin production, and resistance to diet-induced obesity. Proc. Natl. Acad. Sci. USA 2001, 98, 6494-6499. [CrossRef]

45. Gandotra, S.; Lim, K.; Girousse, A.; Saudek, V.; O’Rahilly, S.; Savage, D.B. Human frame shift mutations affecting the carboxyl terminus of perilipin increase lipolysis by failing to sequester the adipose triglyceride lipase (ATGL) coactivator AB-hydrolase-containing 5 (ABHD5). J. Biol. Chem. 2011, 286, 34998-35006. [CrossRef]

46. Gandotra, S.; Le Dour, C.; Bottomley, W.; Cervera, P.; Giral, P.; Reznik, Y.; Charpentier, G.; Auclair, M.; Delépine, M.; Barroso, I.; et al. Perilipin deficiency and autosomal dominant partial lipodystrophy. N. Engl. J. Med. 2011, 364, 740-748. [CrossRef]

47. Greenberg, A.S.; Egan, J.J.; Wek, S.A.; Moos, M.C.; Londos, C.; Kimmel, A.R. Isolation of cDNAs for perilipins A and B: Sequence and expression of lipid droplet-associated proteins of adipocytes. Proc. Natl. Acad. Sci. USA 1993, 90, 12035-12039. [CrossRef] 
48. Sahu-Osen, A.; Montero-Moran, G.; Schittmayer, M.; Fritz, K.; Dinh, A.; Chang, Y.-F.; McMahon, D.; Boeszoermenyi, A.; Cornaciu, I.; Russell, D.; et al. CGI-58/ABHD5 is phosphorylated on Ser239 by protein kinase A: Control of subcellular localization. J. Lipid Res. 2015, 56, 109-121. [CrossRef]

49. Granneman, J.G.; Moore, H.P.H.; Krishnamoorthy, R.; Rathod, M. Perilipin controls lipolysis by regulating the interactions of AB-hydrolase containing 5 (Abhd5) and adipose triglyceride lipase (Atgl). J. Biol. Chem. 2009, 284, 34538-34544. [CrossRef]

50. Granneman, J.G.; Moore, H.P.H.; Mottillo, E.P.; Zhu, Z.; Zhou, L. Interactions of Perilipin-5 (Plin5) with adipose triglyceride lipase. J. Biol. Chem. 2011, 286, 5126-5135. [CrossRef]

51. Macpherson, R.E.K.; Vandenboom, R.; Roy, B.D.; Peters, S.J. Skeletal muscle PLIN3 and PLIN5 are serine phosphorylated at rest and following lipolysis during adrenergic or contractile stimulation. Physiol. Rep. 2013, 1, e00084. [CrossRef] [PubMed]

52. Yamaguchi, T.; Omatsu, N.; Matsushita, S.; Osumi, T. CGI-58 interacts with perilipin and is localized to lipid droplets: Possible involvement of CGI-58 mislocalization in Chanarin-Dorfman syndrome. J. Biol. Chem. 2004, 279, 30490-30497. [CrossRef] [PubMed]

53. Patel, S.; Yang, W.; Kozusko, K.; Saudek, V.; Savage, D.B. Perilipins 2 and 3 lack a carboxy-terminal domain present in perilipin 1 involved in sequestering ABHD5 and suppressing basal lipolysis. Proc. Natl. Acad. Sci. USA 2014, 111, 9163-9168. [CrossRef] [PubMed]

54. Chang, B.H.-J.; Chan, L.; Heird, W.C.; Nannegari, V.; Taniguchi, S.; Paul, A.; Li, L. Protection against Fatty Liver but Normal Adipogenesis in Mice Lacking Adipose Differentiation-Related Protein. Mol. Cell. Biol. 2006, 26, 1063-1076. [CrossRef] [PubMed]

55. Lee, Y.K.; Sohn, J.H.; Han, J.S.; Park, Y.J.; Jeon, Y.G.; Ji, Y.; Dalen, K.T.; Sztalryd, C.; Kimmel, A.R.; Kim, J.B. Perilipin 3 deficiency stimulates thermogenic Beige adipocytes through PPARa activation. Diabetes 2018, 67, 791-804. [CrossRef] [PubMed]

56. Bell, M.; Wang, H.; Chen, H.; McLenithan, J.C.; Gong, D.W.; Yang, R.Z.; Yu, D.; Fried, S.K.; Quon, M.J.; Londos, C.; et al. Consequences of lipid droplet coat protein downregulation in liver cells: Abnormal lipid droplet metabolism and induction of insulin resistance. Diabetes 2008, 57, 2037-2045. [CrossRef]

57. Wolins, N.E.; Skinner, J.R.; Schoenfish, M.J.; Tzekov, A.; Bensch, K.G.; Bickel, P.E. Adipocyte protein S3-12 coats nascent lipid droplets. J. Biol. Chem. 2003, 278, 37713-37721. [CrossRef]

58. Čopič, A.; Antoine-Bally, S.; Giménez-Andrés, M.; La Torre Garay, C.; Antonny, B.; Manni, M.M.; Pagnotta, S.; Guihot, J.; Jackson, C.L. A giant amphipathic helix from a perilipin that is adapted for coating lipid droplets. Nat. Commun. 2018, 9, 1-16. [CrossRef]

59. Itabe, H.; Yamaguchi, T.; Nimura, S.; Sasabe, N. Perilipins: A diversity of intracellular lipid droplet proteins. Lipids Health Dis. 2017, 16, 1-11. [CrossRef]

60. Wu, X.; Chan, L.; Chen, W.; Li, L.; Sleeman, M.; Chang, B. Inactivation of Plin4 downregulates Plin5 and reduces cardiac lipid accumulation in mice. Am. J. Physiol. Metab. 2013, 304, E770-E779.

61. Wu, J.; Li, Z.; Hu, P.; Liu, F.; Zhang, X.; Zhao, Y.; Wang, C.; Zhang, H.; Li, L.; Xu, Y.; et al. Perilipin 5 improves hepatic lipotoxicity by inhibiting lipolysis. Hepatology 2014, 61, 870-882.

62. Drevinge, C.; Dalen, K.T.; Mannila, M.N.; Täng, M.S.; Ståhlman, M.; Klevstig, M.; Lundqvist, A.; Mardani, I.; Haugen, F.; Fogelstrand, P.; et al. Perilipin 5 is protective in the ischemic heart. Int. J. Cardiol. 2016, 219, 446-454. [CrossRef] [PubMed]

63. Kuramoto, K.; Okamura, T.; Yamaguchi, T.; Nakamura, T.Y.; Wakabayashi, S.; Morinaga, H.; Nomura, M.; Yanase, T.; Otsu, K.; Usuda, N.; et al. Perilipin 5, a lipid droplet-binding protein, protects heart from oxidative burden by sequestering fatty acid from excessive oxidation. J. Biol. Chem. 2012, 287, 23852-23863. [CrossRef] [PubMed]

64. Mason, R.R.; Mokhtar, R.; Matzaris, M.; Selathurai, A.; Kowalski, G.M.; Mokbel, N.; Meikle, P.J.; Bruce, C.R.; Watt, M.J. PLIN5 deletion remodels intracellular lipid composition and causes insulin resistance in muscle. Mol. Metab. 2014, 3, 652-663. [CrossRef] [PubMed]

65. Pollak, N.M.; Jaeger, D.; Kolleritsch, S.; Zimmermann, R.; Zechner, R.; Lass, A.; Haemmerle, G. The interplay of protein kinase A and Perilipin 5 regulates cardiac lipolysis. J. Biol. Chem. 2015, 290, 1295-1306. [CrossRef]

66. Kolleritsch, S.; Kien, B.; Schoiswohl, G.; Diwoky, C.; Schreiber, R.; Heier, C.; Maresch, L.K.; Schweiger, M.; Eichmann, T.O.; Stryeck, S.; et al. Low cardiac lipolysis reduces mitochondrial fission and prevents lipotoxic heart dysfunction in Perilipin 5 mutant mice. Cardiovasc. Res. 2020, 116, 339-352. [CrossRef] 
67. Yang, X.; Lu, X.; Lombès, M.; Rha, G.B.; Chi, Y.-I.; Guerin, T.M.; Smart, E.J.; Liu, J. The G(0)/G(1) switch gene 2 regulates adipose lipolysis through association with adipose triglyceride lipase. Cell Metab. 2010, 11, 194-205. [CrossRef]

68. Zandbergen, F.; Mandard, S.; Escher, P.; Tan, N.S.; Patsouris, D.; Jatkoe, T.; Rojas-Caro, S.; Madore, S.; Wahli, W.; Tafuri, S.; et al. The G0/G1 switch gene 2 is a novel PPAR target gene. Biochem. J. 2005, 392, 313-324. [CrossRef]

69. Heckmann, B.L.; Zhang, X.; Xie, X.; Saarinen, A.; Lu, X.; Yang, X.; Liu, J. Defective adipose lipolysis and altered global energy metabolism in mice with adipose overexpression of the lipolytic inhibitor G0/G1 switch gene 2 (G0S2). J. Biol. Chem. 2014, 289, 1905-1916. [CrossRef]

70. Heier, C.; Radner, F.P.W.; Moustafa, T.; Schreiber, R.; Grond, S.; Eichmann, T.O.; Schweiger, M.; Schmidt, A.; Cerk, I.K.; Oberer, M.; et al. G0/G1 switch gene 2 regulates cardiac lipolysis. J. Biol. Chem. 2015, 290, 26141-26150. [CrossRef]

71. Kioka, H.; Kato, H.; Fujikawa, M.; Tsukamoto, O.; Suzuki, T.; Imamura, H.; Nakano, A.; Higo, S.; Yamazaki, S.; Matsuzaki, T.; et al. Evaluation of intramitochondrial ATP levels identifies G0/G1 switch gene 2 as a positive regulator of oxidative phosphorylation. Proc. Natl. Acad. Sci. USA 2014, 111, 273-278. [CrossRef]

72. Yamada, T.; Park, C.S.; Burns, A.; Nakada, D.; Lacorazza, H.D. The cytosolic protein G0S2 maintains quiescence in hematopoietic stem cells. PLoS ONE 2012, 7, e38280. [CrossRef] [PubMed]

73. Welch, C.; Santra, M.K.; El-Assaad, W.; Zhu, X.; Huber, W.E.; Keys, R.A.; Teodoro, J.G.; Green, M.R. Identification of a protein, G0S2, that lacks Bcl-2 homology domains and interacts with and antagonizes Bcl-2. Cancer Res. 2009, 69, 6782-6789. [CrossRef] [PubMed]

74. Gimm, T.; Wiese, M.; Teschemacher, B.; Deggerich, A.; Schödel, J.; Knaup, K.X.; Hackenbeck, T.; Hellerbrand, C.; Amann, K.; Wiesener, M.S.; et al. Hypoxia-inducible protein 2 is a novel lipid droplet protein and a specific target gene of hypoxia-inducible factor-1. FASEB J. 2010, 24, 4443-4458. [CrossRef] [PubMed]

75. Zhang, X.; Saarinen, A.M.; Hitosugi, T.; Wang, Z.; Wang, L.; Ho, T.H.; Liu, J. Inhibition of intracellular lipolysis promotes human cancer cell adaptation to hypoxia. eLife 2017, 6, e31132. [CrossRef]

76. DiStefano, M.T.; Danai, L.V.; Roth Flach, R.J.; Chawla, A.; Pedersen, D.J.; Guilherme, A.; Czech, M.P. The lipid droplet protein hypoxia-inducible gene 2 promotes hepatic triglyceride deposition by inhibiting lipolysis. $J$. Biol. Chem. 2015, 290, 15175-15184. [CrossRef]

77. Padmanabha Das, K.M.; Wechselberger, L.; Liziczai, M.; De la Rosa Rodriguez, M.; Grabner, G.F.; Heier, C.; Viertlmayr, R.; Radler, C.; Lichtenegger, J.; Zimmermann, R.; et al. Hypoxia-inducible lipid droplet-associated protein inhibits adipose triglyceride lipase. J. Lipid Res. 2018, 59, 531-541. [CrossRef]

78. Dijk, W.; Mattijssen, F.; De La Rosa Rodriguez, M.; Valdes, A.L.; Loft, A.; Mandrup, S.; Kalkhoven, E.; Qi, L.; Borst, J.W.; Kersten, S. Hypoxia-inducible lipid droplet-associated is not a direct physiological regulator of lipolysis in adipose tissue. Endocrinology 2017, 158, 1231-1251. [CrossRef]

79. Puri, V.; Konda, S.; Ranjit, S.; Aouadi, M.; Chawla, A.; Chouinard, M.; Chakladar, A.; Czech, M.P. Fat-specific protein 27, a novel lipid droplet protein that enhances triglyceride storage. J. Biol. Chem. 2007, 282, 34213-34218. [CrossRef]

80. Gong, J.; Sun, Z.; Wu, L.; Xu, W.; Schieber, N.; Xu, D.; Shui, G.; Yang, H.; Parton, R.G.; Li, P. Fsp27 promotes lipid droplet growth by lipid exchange and transfer at lipid droplet contact sites. J. Cell Biol. 2011, 195, 953-963. [CrossRef]

81. Wang, J.; Yan, C.; Xu, C.; Chua, B.T.; Li, P.; Chen, F.J. Polybasic RKKR motif in the linker region of lipid droplet (LD)-associated protein CIDEC inhibits LD fusion activity by interacting with acidic phospholipids. J. Biol. Chem. 2018, 293, 19330-19343. [CrossRef]

82. Grahn, T.H.M.; Zhang, Y.; Lee, M.J.; Sommer, A.G.; Mostoslavsky, G.; Fried, S.K.; Greenberg, A.S.; Puri, V. FSP27 and PLIN1 interaction promotes the formation of large lipid droplets in human adipocytes. Biochem. Biophys. Res. Commun. 2013, 432, 296-301. [CrossRef]

83. Sun, Z.; Gong, J.; Wu, H.; Xu, W.; Wu, L.; Xu, D.; Gao, J.; Wu, J.W.; Yang, H.; Yang, M.; et al. Perilipin1 promotes unilocular lipid droplet formation through the activation of Fsp27 in adipocytes. Nat. Commun. 2013, 4, 1594. [CrossRef]

84. Grahn, T.H.M.; Kaur, R.; Yin, J.; Schweiger, M.; Sharma, V.M.; Lee, M.J.; Ido, Y.; Smas, C.M.; Zechner, R.; Lass, A.; et al. Fat-specific protein 27 (FSP27) interacts with adipose triglyceride lipase (ATGL) to regulate lipolysis and insulin sensitivity in human adipocytes. J. Biol. Chem. 2014, 289, 12029-12039. [CrossRef] 
85. Yang, X.; Heckmann, B.L.; Zhang, X.; Smas, C.M.; Liu, J. Distinct Mechanisms Regulate ATGL-Mediated Adipocyte Lipolysis by Lipid Droplet Coat Proteins. Mol. Endocrinol. 2013, 27, 116-126. [CrossRef]

86. Sharma, V.M.; Vestergaard, E.T.; Jessen, N.; Kolind-Thomsen, P.; Nellemann, B.; Nielsen, T.S.; Vendelbo, M.H.; Møller, N.; Sharma, R.; Lee, K.Y.; et al. Growth hormone acts along the PPAR $\gamma$-FSP27 axis to stimulate lipolysis in human adipocytes. Am. J. Physiol.-Endocrinol. Metab. 2019, 316, E34-E42. [CrossRef] [PubMed]

87. Filleur, S.; Nelius, T.; De Riese, W.; Kennedy, R.C. Characterization of pedf: A multi-functional serpin family protein. J. Cell. Biochem. 2009, 106, 769-775. [CrossRef] [PubMed]

88. Famulla, S.; Lamers, D.; Hartwig, S.; Passlack, W.; Horrighs, A.; Cramer, A.; Lehr, S.; Sell, H.; Eckel, J. Pigment epithelium-derived factor (PEDF) is one of the most abundant proteins secreted by human adipocytes and induces insulin resistance and inflammatory signaling in muscle and fat cells. Int. J. Obes. 2011, 35, 762-772. [CrossRef] [PubMed]

89. Dai, Z.; Zhou, T.; Li, C.; Qi, W.; Mao, Y.; Lu, J.; Yao, Y.; Li, L.; Zhang, T.; Hong, H.; et al. Intracellular pigment epithelium-derived factor contributes to triglyceride degradation. Int. J. Biochem. Cell Biol. 2013, 45, 2076-2086. [CrossRef]

90. Chung, C.; Doll, J.A.; Gattu, A.K.; Shugrue, C.; Cornwell, M.; Fitchev, P.; Crawford, S.E. Anti-angiogenic pigment epithelium-derived factor regulates hepatocyte triglyceride content through adipose triglyceride lipase (ATGL). J. Hepatol. 2008, 48, 471-478. [CrossRef]

91. Borg, M.L.; Andrews, Z.B.; Duh, E.J.; Zechner, R.; Meikle, P.J.; Watt, M.J. Pigment epithelium-derived factor regulates lipid metabolism via adipose triglyceride lipase. Diabetes 2011, 60, 1458-1466. [CrossRef]

92. Zhang, H.; Sun, T.; Jiang, X.; Yu, H.; Wang, M.; Wei, T.; Cui, H.; Zhuang, W.; Liu, Z.; Zhang, Z.; et al. PEDF and PEDF-derived peptide 44 mer stimulate cardiac triglyceride degradation via ATGL. J. Transl. Med. 2015, 13, 1-12. [CrossRef]

93. Olzmann, J.A.; Richter, C.M.; Kopito, R.R. Spatial regulation of UBXD8 and p97/VCP controls ATGL-mediated lipid droplet turnover. Proc. Natl. Acad. Sci. USA 2013, 110, 1345-1350. [CrossRef]

94. Imai, N.; Suzuki, M.; Hayashi, K.; Ishigami, M.; Hirooka, Y.; Abe, T.; Shioi, G.; Goto, H.; Fujimoto, T. Hepatocyte-specific depletion of UBXD8 induces periportal steatosis in mice fed a high-fat diet. PLoS ONE 2015, 10, e0127114. [CrossRef]

95. Ellong, E.N.; Soni, K.G.; Bui, Q.T.; Sougrat, R.; Golinelli-Cohen, M.P.; Jackson, C.L. Interaction between the triglyceride lipase ATGL and the arf1 activator GBF1. PLoS ONE 2011, 6, e21889. [CrossRef]

96. Lee, M.C.S.; Miller, E.A.; Goldberg, J.; Orci, L.; Schekman, R. Bi-Directional Protein Transport Between the Er and Golgi. Annu. Rev. Cell Dev. Biol. 2004, 20, 87-123. [CrossRef]

97. Bonifacino, J.S.; Glick, B.S. The Mechanisms of Vesicle Budding and Fusion. Cell 2004, 116, 153-166. [CrossRef]

98. Soni, K.G.; Mardones, G.A.; Sougrat, R.; Smirnova, E.; Jackson, C.L.; Bonifacino, J.S. Coatomer-dependent protein delivery to lipid droplets. J. Cell Sci. 2009, 122, 1834-1841. [CrossRef]

99. Beller, M.; Sztalryd, C.; Southall, N.; Bell, M.; Jäckle, H.; Auld, D.S.; Oliver, B. COPI complex is a regulator of lipid homeostasis. PLoS Biol. 2008, 6, 2530-2549. [CrossRef]

100. Guo, Y.; Walther, T.C.; Rao, M.; Stuurman, N.; Goshima, G.; Terayama, K.; Wong, J.S.; Vale, R.D.; Walter, P.; Farese, R.V. Functional genomic screen reveals genes involved in lipid-droplet formation and utilization. Nature 2008, 453, 657-661. [CrossRef]

101. Kleppe, R.; Martinez, A.; Døskeland, S.O.; Haavik, J. The 14-3-3 proteins in regulation of cellular metabolism. Semin. Cell Dev. Biol. 2011, 22, 713-719. [CrossRef]

102. Takahashi, Y. The 14-3-3 proteins: Gene, gene expression, and function. Neurochem. Res. 2003, 28, $1265-1273$. [CrossRef] [PubMed]

103. Yaffe, M.B.; Rittinger, K.; Volinia, S.; Caron, P.R.; Aitken, A.; Leffers, H.; Gamblin, S.J.; Smerdon, S.J.; Cantley, L.C. The structural basis for 14-3-3:phosphopeptide binding specificity. Cell 1997, 91, 961-971. [CrossRef]

104. Xie, M. AMPK-Dependent Regulation of Lipid Metabolism in the C. elegans Dauer Larva. Ph.D. Thesis, McGill University Montreal, Montréal, QC, Canada, 2013.

105. Gould, S.J.; Collins, C.S. Peroxisomal-protein import: Is it really that complex? Nat. Rev. Mol. Cell Biol. 2002, 3, 382-389. [CrossRef]

106. Harper, C.C.; Berg, J.M.; Gould, S.J. PEX5 binds the PTS1 independently of Hsp70 and the peroxin PEX12. J. Biol. Chem. 2003, 278, 7897-7901. [CrossRef] 
107. Kong, J.; Ji, Y.; Jeon, Y.G.; Han, J.S.; Han, K.H.; Lee, J.H.; Lee, G.; Jang, H.; Choe, S.S.; Baes, M.; et al. Spatiotemporal contact between peroxisomes and lipid droplets regulates fasting-induced lipolysis via PEX5. Nat. Commun. 2020, 11, 1-16. [CrossRef]

108. Vaughan, M.; Berger, J.F.; Steinberg, D. Hormone-sensitive Lipase and Monoglyceride Activities in Adipose Tissue. J. Biol. Chem. 1964, 239, 401-409.

109. Rizack, M.A. Activation of an epinephrine-sensitive lipolytic activity from adipose tissue by adenosine 3', 5' -phosphate. J. Biol. Chem. 1964, 239, 392-395.

110. Hollenberger, C.H.; Raben, M.S.; Astwood, E.B. The lipolytic response to corticotropin. Endocrinology 1961, 68, 589-598. [CrossRef]

111. Lampidonis, A.D.; Rogdakis, E.; Voutsinas, G.E.; Stravopodis, D.J. The resurgence of Hormone-Sensitive Lipase (HSL) in mammalian lipolysis. Gene 2011, 477, 1-11. [CrossRef]

112. Lass, A.; Zimmermann, R.; Oberer, M.; Zechner, R. Lipolysis-A highly regulated multi-enzyme complex mediates the catabolism of cellular fat stores. Prog. Lipid Res. 2011, 50, 14-27. [CrossRef]

113. Marvyn, P.M.; Bradley, R.M.; Button, E.B.; Mardian, E.B.; Duncan, R.E. Fasting upregulates adipose triglyceride lipase and hormone-sensitive lipase levels and phosphorylation in mouse kidney. Biochem. Cell Biol. 2015, 93, 262-267. [CrossRef]

114. Fredrikson, G.; Tornqvist, H.; Belfrage, P. Hormone-sensitive lipase and monoacylglycerol lipase are both required for complete degradation of adipocyte triacylglycerol. Biochim. Biophys. Acta 1986, 876, 288-293. [CrossRef]

115. Wei, S.; Lai, K.; Patel, S.; Piantedosi, R.; Shen, H.; Colantuoni, V.; Kraemer, F.B.; Blaner, W.S. Retinyl ester hydrolysis and retinol efflux from BFC-1 beta adipocytes. J. Biol. Chem. 1997, 272, 14159-14165. [CrossRef] [PubMed]

116. Cook, K.G.; Yeaman, S.J.; Strålfors, P.; Fredrikson, G.; Belfrage, P. Direct evidence that cholesterol ester hydrolase from adrenal cortex is the same enzyme as hormone-sensitive lipase from adipose tissue. Eur. J. Biochem. 1982, 125, 245-249. [CrossRef]

117. Lee, F.T.; Adams, J.B.; Garton, A.J.; Yeaman, S.J. Hormone-sensitive lipase is involved in the hydrolysis of lipoidal derivatives of estrogens and other steroid hormones. Biochim. Biophys. Acta (BBA) 1988, 963, 258-264. [CrossRef]

118. Holm, C.; Osterlund, T. Hormone-sensitive lipase and neutral cholesteryl ester lipase. Methods Mol. Biol. 1999, 109, 109-121.

119. Haemmerle, G.; Zimmermann, R.; Hayn, M.; Theussl, C.; Waeg, G.; Wagner, E.; Sattler, W.; Magin, T.M.; Wagner, E.F.; Zechner, R. Hormone-sensitive Lipase Deficiency in Mice Causes Diglyceride Accumulation in Adipose Tissue, Muscle, and Testis. J. Biol. Chem. 2002, 277, 4806-4815. [CrossRef]

120. Osuga, J.I.; Ishibashi, S.; Oka, T.; Yagyu, H.; Tozawa, R.; Fujimoto, A.; Shionoiri, F.; Yahagi, N.; Kraemer, F.B.; Tsutsumi, O.; et al. Targeted disruption of hormone-sensitive lipase results in male sterility and adipocyte hypertrophy, but not in obesity. Proc. Natl. Acad. Sci. USA 2000, 97, 787-792. [CrossRef]

121. Xia, B.; Cai, G.H.; Yang, H.; Wang, S.P.; Mitchell, G.A.; Wu, J.W. Adipose tissue deficiency of hormone-sensitive lipase causes fatty liver in mice. PLoS Genet. 2017, 13, 1-17. [CrossRef]

122. Albert, J.S.; Yerges-Armstrong, L.M.; Horenstein, R.B.; Pollin, T.I.; Sreenivasan, U.T.; Chai, S.; Blaner, W.S.; Snitker, S.; O'Connell, J.R.; Gong, D.-W.; et al. Null mutation in hormone-sensitive lipase gene and risk of type 2 diabetes. N. Engl. J. Med. 2014, 370, 2307-2315. [CrossRef]

123. Shen, W.J.; Patel, S.; Hong, R.; Kraemer, F.B. Hormone-sensitive lipase functions as an oligomer. Biochemistry 2000, 39, 2392-2398. [CrossRef]

124. Østerlund, T.; Danielsson, B.; Degerman, E.; Contreras, J.A.; Edgren, G.; Davis, R.C.; Schotz, M.C.; Holm, C. Domain-structure analysis of recombinant rat hormone-sensitive lipase. Biochem. J. 1996, 319, 411-420. [CrossRef]

125. ØSterlund, T.; Beussman, D.J.; Julenius, K.; Poon, P.H.; Linse, S.; Shabanowitz, J.; Hunt, D.F.; Schotz, M.C.; Derewenda, Z.S.; Holm, C. Domain identification of hormone-sensitive lipase by circular dichroism and fluorescence spectroscopy, limited proteolysis, and mass spectrometry. J. Biol. Chem. 1999, 274, 15382-15388. [CrossRef]

126. Østerlund, T.; Contreras, J.A.; Holm, C. Identification of essential aspartic acid and histidine residues of hormone-sensitive lipase: Apparent residues of the catalytic triad. FEBS Lett. 1997, 403, 259-262. [CrossRef] 
127. Anthonsen, M.W.; Rönnstrand, L.; Wernstedt, C.; Degerman, E.; Holm, C. Identification of novel phosphorylation sites in hormone-sensitive lipase that are phosphorylated in response to isoproterenol and govern activation properties in vitro. J. Biol. Chem. 1998, 273, 215-221. [CrossRef]

128. Garton, A.J.; Campbell, D.G.; Cohen, P.; Yeaman, S.J. Primary structure of the site on bovine hormone-sensitive lipase phosphorylated by cyclic AMP-dependent protein kinase. FEBS Lett. 1988, 229, 68-72. [CrossRef]

129. GartonN, A.J.; Yeaman, S.J. Identification and role of the basal phosphorylation site on hormone-sensitive lipase. Eur. J. Biochem. 1990, 191, 245-250. [CrossRef]

130. Greenberg, A.S.; Shen, W.J.; Muliro, K.; Patel, S.; Souza, S.C.; Roth, R.A.; Kraemer, F.B. Stimulation of Lipolysis and Hormone-sensitive Lipase via the Extracellular Signal-regulated Kinase Pathway. J. Biol. Chem. 2001, 276, 45456-45461. [CrossRef]

131. Krintel, C.; Osmark, P.; Larsen, M.R.; Resjö, S.; Logan, D.T.; Holm, C. Ser649 and Ser650 are the major determinants of protein kinase A-mediated activation of human hormone-sensitive lipase against lipid substrates. PLOS ONE 2008, 3, e3756. [CrossRef]

132. Stralfors, P.; Belfrage, P. Phosphorylation of hormone-sensitive lipase by cyclic AMP-dependent protein kinase. J. Biol. Chem. 1983, 258, 15146-15152. [PubMed]

133. Kraemer, F.B.; Shen, W.J. Hormone-sensitive lipase: Control of intracellular tri-(di-)acylglycerol and cholesteryl ester hydrolysis. J. Lipid Res. 2002, 43, 1585-1594. [CrossRef] [PubMed]

134. Li, Z.; Sumida, M.; Birchbauer, A.; Schotz, M.C.; Reue, K. Isolation and characterization of the gene for mouse hormone-sensitive lipase. Genomics 1994, 24, 259-265. [CrossRef]

135. Smith, A.J.; Sanders, M.A.; Thompson, B.R.; Londos, C.; Kraemer, F.B.; Bernlohr, D.A. Physical association between the adipocyte fatty acid-binding protein and hormone-sensitive lipase: A fluorescence resonance energy transfer analysis. J. Biol. Chem. 2004, 279, 52399-52405. [CrossRef]

136. Shen, W.J.; Sridhar, K.; Bernlohr, D.A.; Kraemer, F.B. Interaction of rat hormone-sensitive lipase with adipocyte lipid-binding protein. Proc. Natl. Acad. Sci. USA 1999, 96, 5528-5532. [CrossRef]

137. Smith, A.J.; Thompson, B.R.; Sanders, M.A.; Bernlohr, D.A. Interaction of the adipocyte fatty acid-binding protein with the hormone-sensitive lipase: Regulation by fatty acids and phosphorylation. J. Biol. Chem. 2007, 282, 32424-32432. [CrossRef]

138. Smith, A.J.; Sanders, M.A.; Juhlmann, B.E.; Hertzel, A.V.; Bernlohr, D.A. Mapping of the hormone-sensitive lipase binding site on the adipocyte fatty acid-binding protein (AFABP): Identification of the charge quartet on the AFABP/aP2 helix-turn-helix domain. J. Biol. Chem. 2008, 283, 33536-33543. [CrossRef]

139. Jenkins-Kruchten, A.E.; Bennaars-Eiden, A.; Ross, J.R.; Shen, W.J.; Kraemer, F.B.; Bernlohr, D.A. Fatty acid-binding protein-hormone-sensitive lipase interaction: Fatty acid dependence on binding. J. Biol. Chem. 2003, 278, 47636-47643. [CrossRef]

140. Shen, W.J.; Liang, Y.; Hong, R.; Patel, S.; Natu, V.; Sridhar, K.; Jenkins, A.; Bernlohr, D.A.; Kraemer, F.B. Characterization of the Functional Interaction of Adipocyte Lipid-binding Protein with Hormone-sensitive Lipase. J. Biol. Chem. 2001, 276, 49443-49448. [CrossRef]

141. Coe, N.R.; Simpson, M.A.; Bernlohr, D.A. Targeted disruption of the adipocyte lipid-binding protein (aP2 protein) gene impairs fat cell lipolysis and increases cellular fatty acid levels. J. Lipid Res. 1999, 40, 967-972.

142. Londos, C.; Brasaemle, D.L.; Schultz, C.J.; Adler-Wailes, D.C.; Levin, D.M.; Kimmel, A.R.; Rondinone, C.M. On the control of lipolysis in adipocytes. Ann. N. Y. Acad. Sci. 1999, 892, 155-168. [CrossRef]

143. Holm, C. Molecular mechanisms regulating hormone-sensitive lipase and lipolysis. Biochem. Soc. Trans. 2003, 31, 1120-1124. [CrossRef]

144. Brasaemle, D.L.; Levin, D.M.; Adler-Wailes, D.C.; Londos, C. The lipolytic stimulation of 3T3-L1 adipocytes promotes the translocation of hormone-sensitive lipase to the surfaces of lipid storage droplets. Biochim. Biophys. Acta-Mol. Cell Biol. Lipids 2000, 1483, 251-262. [CrossRef]

145. Miyoshi, H.; Souza, S.C.; Zhang, H.H.; Strissel, K.J.; Christoffolete, M.A.; Kovsan, J.; Rudich, A.; Kraemer, F.B.; Bianco, A.C.; Obin, M.S.; et al. Perilipin promotes hormone-sensitive lipase-mediated adipocyte lipolysis via phosphorylation-dependent and -independent mechanisms. J. Biol. Chem. 2006, 281, 15837-15844. [CrossRef]

146. Sztalryd, C.; Xu, G.; Dorward, H.; Tansey, J.T.; Contreras, J.A.; Kimmel, A.R.; Londos, C. Perilipin A is essential for the translocation of hormone-sensitive lipase during lipolytic activation. J. Cell Biol. 2003, 161, 1093-1103. [CrossRef] 
147. Egan, J.J.; Greenberg, A.S.; Chang, M.K.; Wek, S.A.; Moos, M.C.; Londos, C. Mechanism of hormone-stimulated lipolysis in adipocytes: Translocation of hormone-sensitive lipase to the lipid storage droplet. Proc. Natl. Acad. Sci. USA 1992, 89, 8537-8541. [CrossRef]

148. Wang, H.; Hu, L.; Dalen, K.; Dorward, H.; Marcinkiewicz, A.; Russell, D.; Gong, D.; Londos, C.; Yamaguchi, T.; Holm, C.; et al. Activation of hormone-sensitive lipase requires two steps, protein phosphorylation and binding to the PAT-1 domain of lipid droplet coat proteins. J. Biol. Chem. 2009, 284, 32116-32125. [CrossRef]

149. Shen, W.; Patel, S.; Miyoshi, H.; Greenberg, A.S.; Kraemer, F.B.; Endocrinology, D.; Palo, V.A.; Health, A. Functional interaction of hormone-sensitive lipase and perilipin in lipolysis. J. Lipid Res. 2009, 50, 2306-2313. [CrossRef]

150. Garcia, A.; Subramanian, V.; Sekowski, A.; Bhattacharyya, S.; Love, M.W.; Brasaemle, D.L. The Amino and Carboxyl Termini of Perilipin A Facilitate the Storage of Triacylglycerols. J. Biol. Chem. 2004, 279, 8409-8416. [CrossRef]

151. Brasaemle, D.L.; Dolios, G.; Shapiro, L.; Wang, R. Proteomic analysis of proteins associated with lipid droplets of basal and lipolytically stimulated 3T3-L1 adipocytes. J. Biol. Chem. 2004, 279, 46835-46842. [CrossRef]

152. Shen, W.J.; Patel, S.; Eriksson, J.E.; Kraemer, F.B. Vimentin is a functional partner of hormone sensitive lipase and facilitates lipolysis. J. Proteome Res. 2010, 9, 1786-1794. [CrossRef]

153. Kumar, N.; Robidoux, J.; Daniel, K.W.; Guzman, G.; Floering, L.M.; Collins, S. Requirement of vimentin filament assembly for beta3-adrenergic receptor activation of ERK MAP kinase and lipolysis. J. Biol. Chem. 2007, 282, 9244-9250. [CrossRef]

154. Lieber, J.G.; Evans, R.M. Disruption of the vimentin intermediate filament system during adipose conversion of 3T3-L1 cells inhibits lipid droplet accumulation. J. Cell Sci. 1996, 109, 3047-3058.

155. Thorn, H.; Stenkula, K.G.; Karlsson, M.; Ortegren, U.; Nystrom, F.H.; Gustavsson, J.; Stralfors, P. Cell surface orifices of caveolae and localization of caveolin to the necks of caveolae in adipocytes. Mol. Biol. Cell 2003, 14, 3967-3976. [CrossRef]

156. Pilch, P.F.; Liu, L. Fat caves: Caveolae, lipid trafficking and lipid metabolism in adipocytes. Trends Endocrinol. Metab. 2011, 22, 318-324. [CrossRef]

157. Liu, L.; Brown, D.; McKee, M.; Lebrasseur, N.K.; Yang, D.; Albrecht, K.H.; Ravid, K.; Pilch, P.F. Deletion of Cavin/PTRF causes global loss of caveolae, dyslipidemia, and glucose intolerance. Cell Metab. 2008, 8, 310-317. [CrossRef]

158. Hayashi, Y.K.; Matsuda, C.; Ogawa, M.; Goto, K.; Tominaga, K.; Mitsuhashi, S.; Park, Y.-E.; Nonaka, I.; Hino-Fukuyo, N.; Haginoya, K.; et al. Human PTRF mutations cause secondary deficiency of caveolins resulting in muscular dystrophy with generalized lipodystrophy. J. Clin. Investig. 2009, 119, 2623-2633. [CrossRef]

159. Shastry, S.; Delgado, M.R.; Dirik, E.; Turkmen, M.; Agarwal, A.K.; Garg, A. Congenital generalized lipodystrophy, type 4 (CGL4) associated with myopathy due to novel PTRF mutations. Am. J. Med. Genet. A 2010, 152A, 2245-2253. [CrossRef]

160. Ding, S.; Lee, M.; Summer, R.; Liu, L.; Fried, S.K.; Pilch, P.F. Pleiotropic Effects of Cavin-1 Deficiency on Lipid Metabolism. J. Biol. Chem. 2014, 289, 8473-8483. [CrossRef]

161. Örtegren, U.; Yin, L.; Oest, A.; Karlsson, H.; Nystrom, F.H.; Strålfors, P. Separation and characterization of caveolae subclasses in the plasma membrane of primary adipocytes; segregation of specific proteins and functions. FEBS J. 2006, 273, 3381-3392. [CrossRef]

162. Aboulaich, N.; Örtegren, U.; Vener, A.V.; Strålfors, P. Association and insulin regulated translocation of hormone-sensitive lipase with PTRF. Biochem. Biophys. Res. Commun. 2006, 350, 657-661. [CrossRef]

163. Zhou, S.; Guo, L.; Wang, X.; Liu, Y.; Peng, W.; Liu, Y. Acetylation of Cavin-1 Promotes Lipolysis in White Adipose Tissue. Mol. Cell. Biol. 2017, 37, 1-14. [CrossRef]

164. Eissing, L.; Scherer, T.; Toedter, K.; Knippschild, U.; Greve, J.W.; Buurman, W.A.; Pinnschmidt, H.O.; Rensen, S.S.; Wolf, A.M.; Bartelt, A.; et al. De novo lipogenesis in human fat and liver is linked to ChREBP- $\beta$ and metabolic health. Nat. Commun. 2013, 4, 1528. [CrossRef]

165. Herman, M.A.; Peroni, O.D.; Villoria, J.; Schön, M.R.; Abumrad, N.A.; Blüher, M.; Klein, S.; Kahn, B.B. A novel ChREBP isoform in adipose tissue regulates systemic glucose metabolism. Nature 2012, 484, 333-340. [CrossRef] 
166. Hoffstedt, J.; Förster, D.; Löfgren, P. Impaired subcutaneous adipocyte lipogenesis is associated with systemic insulin resistance and increased apolipoprotein B/AI ratio in men and women. J. Intern. Med. 2007, 100, 131-139. [CrossRef]

167. Morigny, P.; Houssier, M.; Mairal, A.; Ghilain, C.; Mouisel, E.; Benhamed, F.; Masri, B.; Recazens, E.; Denechaud, P.; Tavernier, G.; et al. Interaction between hormone-sensitive lipase and ChREBP in fat cells controls insulin sensitivity. Nat. Metab. 2019, 1, 133-146. [CrossRef]

168. Girousse, A.; Tavernier, G.; Valle, C.; Moro, C.; Mejhert, N.; Dinel, A.-L.; Houssier, M.; Roussel, B.; Besse-Patin, A.; Combes, M.; et al. Partial inhibition of adipose tissue lipolysis improves glucose metabolism and insulin sensitivity without alteration of fat mass. PLoS Biol. 2013, 11, e1001485. [CrossRef]

169. Martinez-Lopez, N.; Garcia-Macia, M.; Sahu, S.; Athonvarangkul, D.; Liebling, E.; Merlo, P.; Cecconi, F.; Schwartz, G.J.; Singh, R. Autophagy in the CNS and Periphery Coordinate Lipophagy and Lipolysis in the Brown Adipose Tissue and Liver. Cell Metab. 2016, 23, 113-127. [CrossRef]

170. Miller, W.L.; Strauss, J.F. Molecular pathology and mechanism of action of the steroidogenic acute regulatory protein, STAR. J. Steroid Biochem. Mol. Biol. 1999, 69, 131-141. [CrossRef]

171. Shen, W.J.; Patel, S.; Natu, V.; Hong, R.; Wang, J.; Azhar, S.; Kraemer, F.B. Interaction of Hormone-sensitive Lipase with Steroidogeneic Acute Regulatory Protein: Facilitation of cholesterol transfer in adrenal. J. Biol. Chem. 2003, 278, 43870-43876. [CrossRef]

172. Karlsson, M.; Contreras, J.A.; Hellman, U.; Tornqvist, H.; Holm, C. cDNA Cloning, Tissue Distribution, and Identification of the Catalytic Triad of Monoglyceride Lipase. J. Biol. Chem. 1997, 272, 27218-27223. [CrossRef]

173. Labar, G.; Bauvois, C.; Borel, F.; Ferrer, J.L.; Wouters, J.; Lambert, D.M. Crystal structure of the human monoacylglycerol lipase, a key actor in endocannabinoid signaling. ChemBioChem 2010, 11, 218-227. [CrossRef]

174. Bertrand, T.; Augé, F.; Houtmann, J.; Rak, A.; Vallée, F.; Mikol, V.; Berne, P.F.; Michot, N.; Cheuret, D.; Hoornaert, C.; et al. Structural Basis for Human Monoglyceride Lipase Inhibition. J. Mol. Biol. 2010, 396, 663-673. [CrossRef]

175. Karlsson, M.; Reue, K.; Xia, Y.R.; Lusis, A.J.; Langin, D.; Tornqvist, H.; Holm, C. Exon-intron organization and chromosomal localization of the mouse monoglyceride lipase gene. Gene 2001, 272, 11-18. [CrossRef]

176. Tornqvist, H.; Belfrage, P. Purification and some properties of a monoacylglycerol-hydrolyzing enzyme of rat adipose tissue. J. Biol. Chem. 1976, 251, 813-819.

177. Savinainen, J.R.; Kansanen, E.; Pantsar, T.; Navia-Paldanius, D.; Parkkari, T.; Lehtonen, M.; Laitinen, T.; Nevalainen, T.; Poso, A.; Levonen, A.L.; et al. Robust hydrolysis of prostaglandin glycerol esters by human monoacylglycerol lipase (MAGL). Mol. Pharmacol. 2014, 86, 522-535. [CrossRef]

178. Heier, C.; Taschler, U.; Radulovic, M.; Aschauer, P.; Eichmann, T.O.; Grond, S.; Wolinski, H.; Oberer, M.; Zechner, R.; Kohlwein, S.D.; et al. Monoacylglycerol lipases act as evolutionarily conserved regulators of non-oxidative ethanol metabolism. J. Biol. Chem. 2016, 291, 11865-11875. [CrossRef]

179. Yoshida, K.; Kita, Y.; Tokuoka, S.M.; Hamano, F.; Yamazaki, M.; Sakimura, K.; Kano, M.; Shimizu, T. Monoacylglycerol lipase deficiency affects diet-induced obesity, fat absorption, and feeding behavior in CB1 cannabinoid receptor-deficient mice. FASEB J. 2019, 33, 2484-2497. [CrossRef]

180. Douglass, J.D.; Zhou, Y.X.; Wu, A.; Zadrogra, J.A.; Gajda, A.M.; Lackey, A.I.; Lang, W.; Chevalier, K.M.; Sutton, S.W.; Zhang, S.P.; et al. Global deletion of MGL in mice delays lipid absorption and alters energy homeostasis and diet-induced obesity. J. Lipid Res. 2015, 56, 1153-1171. [CrossRef]

181. Tardelli, M.; Bruschi, F.V.; Claudel, T.; Fuchs, C.D.; Auer, N.; Kunczer, V.; Stojakovic, T.; Scharnagl, H.; Habib, A.; Grabner, G.F.; et al. Lack of monoacylglycerol lipase prevents hepatic steatosis by favoring lipid storage in adipose tissue and intestinal malabsorption. J. Lipid Res. 2019, 60, 1284-1292. [CrossRef]

182. Dinh, T.P.; Carpenter, D.; Leslie, F.M.; Freund, T.F.; Katona, I.; Sensi, S.L.; Kathuria, S.; Piomelli, D. Brain monoglyceride lipase participating in endocannabinoid inactivation. Proc. Natl. Acad. Sci. USA 2002, 99, 10819-10824. [CrossRef]

183. Taschler, U.; Radner, F.P.W.; Heier, C.; Schreiber, R.; Schweiger, M.; Schoiswohl, G.; Preiss-Landl, K.; Jaeger, D.; Reiter, B.; Koefeler, H.C.; et al. Monoglyceride lipase deficiency in mice impairs lipolysis and attenuates diet-induced insulin resistance. J. Biol. Chem. 2011, 286, 17467-17477. [CrossRef] 
184. Chanda, P.K.; Gao, Y.; Mark, L.; Btesh, J.; Strassle, B.W.; Lu, P.; Piesla, M.J.; Zhang, M.-Y.; Bingham, B.; Uveges, A.; et al. Monoacylglycerol lipase activity is a critical modulator of the tone and integrity of the endocannabinoid system. Mol. Pharmacol. 2010, 78, 996-1003. [CrossRef]

185. Schlosburg, J.E.; Blankman, J.L.; Long, J.Z.; Nomura, D.K.; Pan, B.; Kinsey, S.G.; Nguyen, P.T.; Ramesh, D.; Booker, L.; Burston, J.J.; et al. Chronic monoacylglycerol lipase blockade causes functional antagonism of the endocannabinoid system. Nat. Neurosci. 2010, 13, 1113-1119. [CrossRef]

186. MacHado, J.D.; Díaz-Vera, J.; Domínguez, N.; Álvarez, C.M.; Pardo, M.R.; Borges, R. Chromogranins A and $\mathrm{B}$ as regulators of vesicle cargo and exocytosis. Cell. Mol. Neurobiol. 2010, 30, 1181-1187. [CrossRef]

187. Stelzl, U.; Worm, U.; Lalowski, M.; Haenig, C.; Brembeck, F.H.; Goehler, H.; Stroedicke, M.; Zenkner, M.; Schoenherr, A.; Koeppen, S.; et al. A human protein-protein interaction network: A resource for annotating the proteome. Cell 2005, 122, 957-968. [CrossRef]

188. Rajasekaran, D.; Jariwala, N.; Mendoza, R.G.; Robertson, C.L.; Akiel, M.A.; Dozmorov, M.; Fisher, P.B.; Sarkar, D. Staphylococcal nuclease and tudor domain containing 1 (SND1 protein) promotes hepatocarcinogenesis by inhibiting monoglyceride lipase (MGLL). J. Biol. Chem. 2016, 291, 10736-10746. [CrossRef]

189. Jariwal, N.; Rajasekaran, D.; Srivastava, J.; Gredler, R.; Akiel, M.A.; Robertson, C.L.; Emdad, L.; Fisher, P.B.; Sarkar, D. Role of the staphylococcal nuclease and tudor domain containing 1 in oncogenesis (Review). Int. J. Oncol. 2015, 46, 465-473. [CrossRef]

190. Nomura, D.K.; Long, J.Z.; Niessen, S.; Hoover, H.S.; Cravatt, B.F. Monoacylglycerol lipase regulates a fatty acid network that promotes cancer pathogenesis. Cell 2011, 140, 49-61. [CrossRef]

191. Sun, H.; Jiang, L.; Luo, X.; Jin, W.; He, Q.; An, J.; Lui, K.; Shi, J.; Rong, R.; Su, W.; et al. Potential tumor-suppressive role of monoglyceride lipase in human colorectal cancer. Oncogene 2013, 32, 234-241. [CrossRef]

192. Carbonetti, G.; Wilpshaar, T.; Kroonen, J.; Studholme, K.; Converso, C.; d'Oelsnitz, S.; Kaczocha, M. FABP5 coordinates lipid signaling that promotes prostate cancer metastasis. Sci. Rep. 2019, 9, 18944. [CrossRef]

193. Schweiger, M.; Romauch, M.; Schreiber, R.; Grabner, G.F.; Hütter, S.; Kotzbeck, P.; Benedikt, P.; Eichmann, T.O.; Yamada, S.; Knittelfelder, O.; et al. Pharmacological inhibition of adipose triglyceride lipase corrects high-fat diet-induced insulin resistance and hepatosteatosis in mice. Nat. Commun. 2017, 8, 14859. [CrossRef]

194. Ebdrup, S.; Refsgaard, H.H.F.; Fledelius, C.; Jacobsen, P. Synthesis and structure-activity relationship for a novel class of potent and selective carbamate-based inhibitors of hormone selective lipase with acute in vivo antilipolytic effects. J. Med. Chem. 2007, 50, 5449-5456. [CrossRef]

195. Grabner, G.F.; Zimmermann, R.; Schicho, R.; Taschler, U. Monoglyceride lipase as a drug target: At the crossroads of arachidonic acid metabolism and endocannabinoid signaling. Pharmacol. Ther. 2017, 175, 35-46. [CrossRef]

196. Scott, D.E.; Bayly, A.R.; Abell, C.; Skidmore, J. Small molecules, big targets: Drug discovery faces the protein-protein interaction challenge. Nat. Rev. Drug Discov. 2016, 15, 533-550. [CrossRef]

(C) 2020 by the authors. Licensee MDPI, Basel, Switzerland. This article is an open access article distributed under the terms and conditions of the Creative Commons Attribution (CC BY) license (http://creativecommons.org/licenses/by/4.0/). 